\author{
Check for updates \\ Cite this: Green Chem., 2021, 23, 752 \\ Received 29th September 2020, \\ Accepted 7th January 2021 \\ DOI: $10.1039 / \mathrm{dOgc03290e}$ \\ rsc.li/greenchem
}

\section{Enzymatic production of $\beta$-glucose 1,6-bisphosphate through manipulation of catalytic magnesium coordination $\uparrow$}

\author{
Henry P. Wood, (D) a Nicola J. Baxter, ${ }^{a, b}$ F. Aaron Cruz-Navarrete, (iD ${ }^{a}$ Clare R. Trevitt, ${ }^{a}$ \\ Andrea M. Hounslow ${ }^{a}$ and Jonathan P. Waltho (D) *a,b
}

\begin{abstract}
Manipulation of enzyme behaviour represents a sustainable technology that can be harnessed to enhance the production of valuable metabolites and chemical precursors. $\beta$-Glucose 1,6 -bisphosphate ( $\beta$ G16BP) is a native reaction intermediate in the catalytic cycle of $\beta$-phosphoglucomutase ( $\beta$ PGM) that has been proposed as a treatment for human congenital disorder of glycosylation involving phosphomannomutase 2 . Strategies to date for the synthesis of $\beta$ G16BP suffer from low yields or use chemicals and procedures with significant environmental impacts. Herein, we report the efficient enzymatic synthesis of anomer-specific $\beta G 16 B P$ using the D170N variant of $\beta P G M\left(\beta P G M_{D 170 N}\right)$, where the aspartate to asparagine substitution at residue 170 perturbs the coordination of a catalytic magnesium ion. Through combined use of NMR spectroscopy and kinetic assays, it is shown that the weakened affinity and reactivity of $\beta$ PGM $M_{D 170 N}$ towards $\beta G 16 B P$ contributes to the pronounced retardation of the second step in the two-step catalytic cycle, which causes a marked accumulation of $\beta$ G16BP, especially at elevated $\mathrm{MgCl}_{2}$ concentrations. Purification, employing a simple environmentally considerate precipitation procedure requiring only a standard biochemical toolset, results in a BG16BP product with high purity and yield. Overall, this synthesis strategy illustrates how manipulation of the catalytic magnesium coordination of an enzyme can be utilised to generate large quantities of a valuable metabolite.
\end{abstract}

Enzyme engineering represents an emerging technology with the potential to deliver solutions to many sustainable development problems. ${ }^{1,2}$ Biofuel production, plastic degradation and the clean generation of industrial reagents and precursors are three examples of areas where enzymes already make a signifi-

\footnotetext{
${ }^{a}$ Krebs Institute for Biomolecular Research, Department of Molecular Biology and Biotechnology, The University of Sheffield, Sheffield, S10 2TN, UK.

E-mail: j.waltho@sheffield.ac.uk; Tel: +4411422717

${ }^{b}$ Manchester Institute of Biotechnology and School of Chemistry, The University of Manchester, Manchester, M1 TDN, UK

$\dagger$ Electronic supplementary information (ESI) available. See DOI: 10.1039/ doge03290e
}

cant contribution. ${ }^{3-6}$ Research that aims to foster a deeper understanding of enzyme catalysis is therefore of great interest. Phosphoryl transfer enzymes are at the forefront of research models for investigating the origins of enzyme catalysis because they exhibit some of the largest enzymatic rate enhancements known. ${ }^{7,8}$ In addition, phosphate esters are often covalently incorporated into pharmaceutical products to improve bioavailability. ${ }^{9,10} \beta$-Phosphoglucomutase ( $\beta$ PGM; EC 5.4.2.6) has emerged as an archetypal enzyme in the study of phosphoryl transfer, and substantial progress has been made in understanding its mechanism of catalysis. ${ }^{11-16}$ This magnesium-dependent enzyme from Lactococcus lactis (subspecies lactis IL1403) catalyses the isomerisation between $\beta$-glucose 1-phosphate ( $\beta \mathrm{G} 1 \mathrm{P})$ and glucose 6-phosphate (G6P) via a $\beta$-glucose 1,6-phosphate ( $\beta$ G16BP) intermediate, which is released to solution before rebinding in the alternate orientation (Fig. 1). ${ }^{11,17}$ The $\beta$ G1P substrate of $\beta$ PGM is commercially unavailable, but appropriate quantities for research have been produced enzymatically from maltose using a simple method involving maltose phosphorylase. ${ }^{18}$ To initiate the catalytic cycle, $\beta$ PGM requires priming with a phosphorylating agent to generate the active phospho-enzyme $\left(\beta \mathrm{PGM}^{\mathrm{P}}\right.$, phosphorylated on residue D8) and $\beta$ G16BP can perform this role in vivo. Since $\beta \mathrm{G} 16 \mathrm{BP}$ is also commercially unavailable, alternative phosphorylating agents such as acetyl phosphate (AcP), fructose 1,6-bisphosphate (F16BP) and $\alpha$-glucose 1,6-bisphosphate $(\alpha \mathrm{G} 16 \mathrm{BP})$ have been used to generate $\beta \mathrm{PGM}^{\mathrm{P}}$ in vitro, but these compounds are less effective and produce complicated kinetic behaviour. ${ }^{12,19}$

$\beta$ G16BP has also been identified as a potential pharmacological chaperone for the management of a human congenital disorder of glycosylation involving phosphomannomutase $2 .{ }^{20}$ Acting as a weakly binding competitive inhibitor, $\beta$ G16BP is able to rescue the compromised activity of pathological variants of phosphomannomutase 2 by stabilising the protein fold. Therefore, further investigations of phosphomannomutase 2 and of $\beta$ PGM are reliant on the availability of substantial quantities of $\beta$ G16BP. Three strategies have been reported pre- 


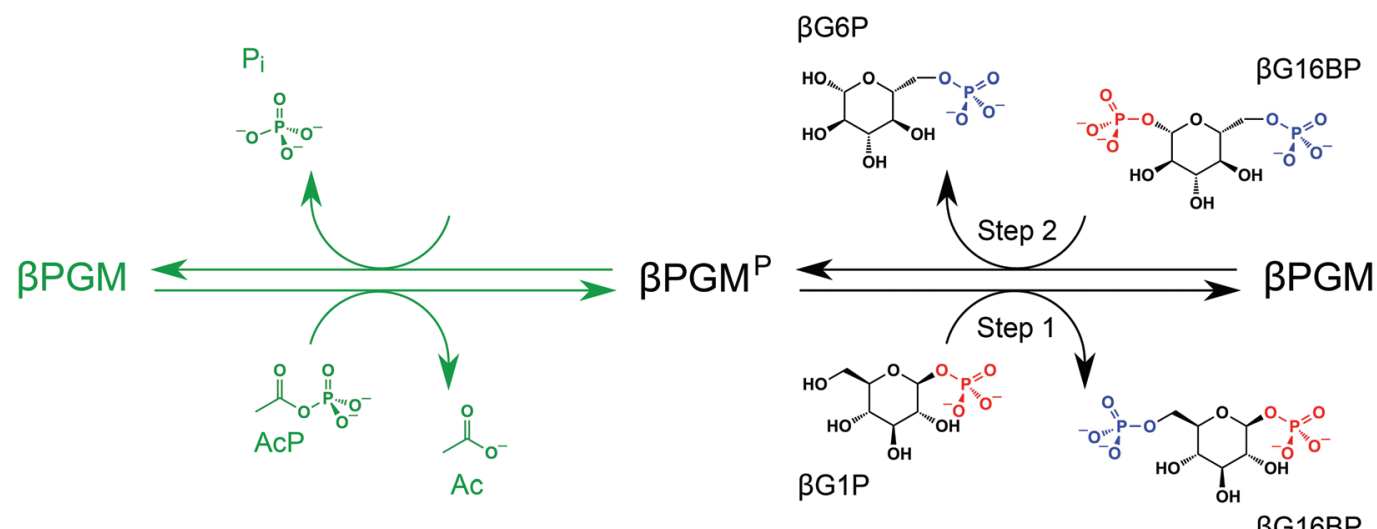

Fig. 1 In vitro phosphorylation and catalytic cycle of $\beta$ PGM. AcP phosphorylates $\beta$ PGM generating $\beta$ PGM ${ }^{P}$ (phosphorylated on residue D8) in a $\mathrm{Mg}^{2+}$-independent reaction (green ink). In the $\mathrm{Mg}^{2+}$-dependent catalytic cycle (black ink), Step 1 involves phosphoryl transfer from $\beta P G M^{P}$ to the $\beta$ G1P substrate forming the $\beta$ G16BP intermediate, whereas Step 2 comprises phosphoryl transfer from $\beta$ G16BP (bound in the alternate orientation) to $\beta P G M$ forming the G6P product and regeneration of $\beta P G M P$. In the phosphorylated glucosaccharide structures, 1-phosphate groups are coloured red and 6-phosphate groups are coloured blue. The black arrows denote the dominant direction of the corresponding reversible reactions. In the absence of the $\beta$ G1P substrate, $\beta$ PGM ${ }^{P}$ has a half-life of $30 \mathrm{~s}$ and hydrolyses readily to $\beta P G M$ liberating inorganic phosphate $\left(\mathrm{P}_{\mathrm{i}}\right){ }^{12}$

viously for the synthesis of $\beta$ G16BP; however, each of these methods either delivers low yields or uses chemicals and procedures with significant environmental impacts. Firstly, the chemical synthesis of $\beta$ G16BP from $\alpha$-glucose involves an eight-step protocol, requiring considerable time and technical expertise, together with the use of harmful and environmentally hazardous reagents. ${ }^{12}$ Low yields are obtained, since the $\beta$-anomer must be selected carefully on the basis of solubility from a racemic mixture of glucosaccharide products. Secondly, an enzymatic production method utilises a non-native reaction of phosphofructokinase to generate $\beta$ G16BP from $\beta$ G1P using adenosine triphosphate as the phosphoryl donor. ${ }^{17,20}$ Purification of the product, though, cannot be achieved simply using precipitation procedures, since contaminating adenosine diphosphate co-precipitates with $\beta \mathrm{G} 16 \mathrm{BP},{ }^{21}$ and therefore ion-exchange HPLC purification is required. The use of HPLC columns is inherently damaging to the environment owing to the use of triethylammonium bicarbonate as a volatile buffer mobile phase, which during its production results in the release of large quantities of carbon dioxide. ${ }^{22}$ Thirdly, an extraction method involves the removal of $\beta$ G16BP from a variant of $\beta$ PGM that co-purifies with a stoichiometric quantity of the molecule. ${ }^{18}$ This method suffers from low yields, since it relies on very high recombinant $\beta$ PGM production levels, and requires a week-long protein growth and purification procedure for each new batch of $\beta$ G16BP. The limited availability of $\beta \mathrm{G} 16 \mathrm{BP}$ therefore represents a significant barrier to the structural, kinetic and therapeutic investigations of phosphomutase enzymes. Herein, we describe a room-temperature, enzymatic method using the D170N variant of $\beta$ PGM $\left(\beta \mathrm{PGM}_{\mathrm{D} 170 \mathrm{~N}}\right)$ for the production of $100 \%$ anomer-specific $\beta$ G16BP, which requires only micromolar quantities of enzyme and a simple environmentally considerate purification procedure that can be performed easily by a non-chemist over the course of two days. Through combined use of NMR spec- troscopy and kinetic assays, it is shown that the weakened affinity and reactivity of $\beta \mathrm{PGM}_{\mathrm{D} 170 \mathrm{~N}}$ towards $\beta \mathrm{G} 16 \mathrm{BP}$ contributes to the pronounced retardation of the second step in the two-step catalytic cycle, which causes a marked accumulation of $\beta \mathrm{G} 16 \mathrm{BP}$, especially at elevated $\mathrm{MgCl}_{2}$ concentrations. More generally, this enzymatic synthesis strategy illustrates how manipulation of catalytic magnesium coordination can be utilised to generate large quantities of a valuable metabolite.

$\beta$ PGM has two phosphoryl transfer steps in its catalytic cycle: Step 1 comprises phosphoryl transfer from $\beta \mathrm{PGM}^{\mathrm{P}}$ to the $\beta$ G1P substrate forming the $\beta$ G16BP reaction intermediate, whereas Step 2 involves phosphoryl transfer from $\beta$ G16BP to $\beta$ PGM forming the G6P product and regeneration of $\beta$ PGM $^{\mathrm{P}}$ (Fig. 1). When wild-type $\beta \mathrm{PGM}\left(\beta_{\mathrm{PGM}} \mathrm{WT}\right)$ is incubated in the presence of $\mathrm{Mg}^{2+}$ ions, with $20 \mathrm{mM}$ AcP as the phosphorylating agent and $10 \mathrm{mM} \beta \mathrm{G} 1 \mathrm{P}$ as a substrate, $\beta$ G16BP generated in the catalytic cycle does not accumulate to detectable levels when monitored using ${ }^{31} \mathrm{P}$ NMR experiments. ${ }^{18}$ Instead, $\beta$ G16BP rebinds the enzyme with micromolar affinity in the alternate orientation, for the Step 2 reaction. Thus, the tight binding and high reactivity of $\beta$ G16BP maintain a low steady state concentration, which precludes the harvesting of this species in useful quantities. The crystal structures of substratefree $\beta \mathrm{PGM}_{\mathrm{WT}}$ (PDB: $6 \mathrm{YDL}^{23}$ ) and of the $\beta \mathrm{PGM}_{\mathrm{WT}}^{\mathrm{P}}$ analogue complex $\left(\beta \mathrm{PGM}_{\mathrm{WT}}: \mathrm{BeF}_{3}\right.$ complex, PDB: $\left.2 \mathrm{WFA}^{15}\right)$ indicate that the catalytic magnesium ion $\left(\mathrm{Mg}_{\text {cat }}\right)$ is coordinated through three enzyme atoms in the former and four phospho-enzyme atoms in the latter (Fig. 2). Therefore, the differential coordination of $\mathrm{Mg}_{\text {cat }}$ provides an appropriate target with which to manipulate $\beta$ PGM to shift the balance in the rate constants of Step 1 and Step 2 so that $\beta$ G16BP will accumulate to a greater extent. Two potential strategies emerged where Step 2 could be retarded with respect to Step 1, which involved either performing the reactions of the catalytic cycle under $\mathrm{Mg}^{2+}$-free conditions or perturbing $\mathrm{Mg}_{\text {cat }}$ coordination through point 

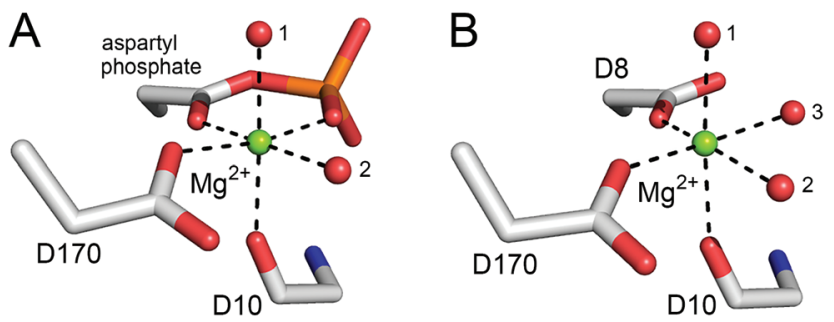

Fig. 2 Comparison of octahedral $\mathrm{Mg}_{\text {cat }}$ coordination in $\beta P G M_{W T}{ }^{P}$ (Step 1) and $\beta P G M_{W T}$ (Step 2). (A) A model of $\beta P G M_{W T}{ }^{P}$ derived from the crystal structure of the $\beta \mathrm{PGM}_{\mathrm{WT}}: \mathrm{BeF}_{3}$ complex $\left(\mathrm{PDB}: 2 \mathrm{WFA}{ }^{15}\right.$ ) showing $\mathrm{Mg}_{\text {cat }}$ coordination. The ligands comprise a carboxylate oxygen atom of residue $\mathrm{D} 170$, the carbonyl oxygen atom of residue D10 and two water molecules (indicated by numbers), together with the carboxylate oxygen atom and a phosphate oxygen atom of the D8 aspartyl phosphate moiety, creating bidentate coordination of $\mathrm{Mg}_{\text {cat }}$ in a six-membered ring of atoms. (B) The crystal structure of substrate-free $\beta P G M_{W T}$ (PDB: $6 \mathrm{YDL}^{23}$ ) showing $\mathrm{Mg}_{\text {cat }}$ coordination. The ligands involve a carboxylate oxygen atom of residue D8, a carboxylate oxygen atom of residue $\mathrm{D} 170$, the carbonyl oxygen atom of residue D10 and three water molecules (indicated by numbers). $\mathrm{Mg}_{\mathrm{cat}}$ is depicted as a green sphere, water molecules are illustrated as red spheres and metal ion coordination is shown as black dashes.

mutation to alter its binding properties. In either scenario, it was hypothesised that $\beta$ PGM with a compromised $\mathrm{Mg}_{\text {cat }}$ site could be phosphorylated efficiently by reactive phosphorylating agents such as AcP, thereby generating $\beta \mathrm{PGM}^{\mathrm{P}}$ and sub- sequent reaction with $\beta$ G1P to produce $\beta$ G16BP in Step 1 (Fig. 1). In contrast, phosphorylation of $\beta$ PGM by $\beta$ G16BP in Step 2 is less likely under these circumstances, which would lead to an accumulation of the reaction intermediate that could be harvested.

To explore whether AcP is able to phosphorylate $\mathrm{Mg}_{\text {cat }}$-free $\beta \mathrm{PGM}_{\mathrm{WT}},{ }^{31} \mathrm{P}$ NMR experiments were acquired to measure the change in AcP concentration over time in the presence and absence of $300 \mu \mathrm{M} \beta \mathrm{PGM}_{\mathrm{WT}}$. The addition of $\beta \mathrm{PGM}_{\mathrm{WT}}$ resulted in a $25 \%$ increase in the rate of AcP hydrolysis (Fig. 3A), implying that $\beta_{\mathrm{PGM}}{ }_{\mathrm{WT}}^{\mathrm{P}}$ is generated and hydrolysed in the absence of $\mathrm{Mg}_{\text {cat }}$. Consequently, the Step 1 reaction between $\mathrm{Mg}_{\text {cat }}$-free $\beta \mathrm{PGM}_{\mathrm{WT}}$ and $10 \mathrm{mM} \beta \mathrm{G} 1 \mathrm{P}$ in the presence of $50 \mathrm{mM} \mathrm{AcP}$, together with the Step 2 production of G6P, was monitored using ${ }^{31} \mathrm{P}$ NMR time-course experiments. However, there was no detectable accumulation of $\beta$ G16BP (Fig. $4 \mathrm{~A}-\mathrm{C}$ ) and the appearance of G6P product proceeded with a rate constant of $6.7 \times 10^{-3} \mathrm{~s}^{-1}$, which is 4 orders of magnitude smaller than the rate constant observed in the presence of $5 \mathrm{mM} \mathrm{MgCl}_{2}{ }^{18}$ Hence, the observed enzymatic activity may simply arise due to the presence of very low levels of residual $\mathrm{Mg}^{2+}$ ions associated with the reagents. Taken together, these results indicate that both $\mathrm{Mg}_{\text {cat }}$-bound $\beta \mathrm{PGM}_{\mathrm{WT}}{ }^{\mathrm{P}}$ and $\mathrm{Mg}_{\text {cat }}$-free $\beta \mathrm{PGM}_{\mathrm{WT}}{ }^{\mathrm{P}}$ can be generated by AcP, but both the Step 1 and Step 2 phosphoryl transfer reactions are seriously impaired by the absence of $\mathrm{Mg}_{\text {cat }}$.

Given the low rate of $\beta$ G16BP production in the absence of $\mathrm{Mg}^{2+}$ ions in the reaction buffer, a more subtle modification of
A
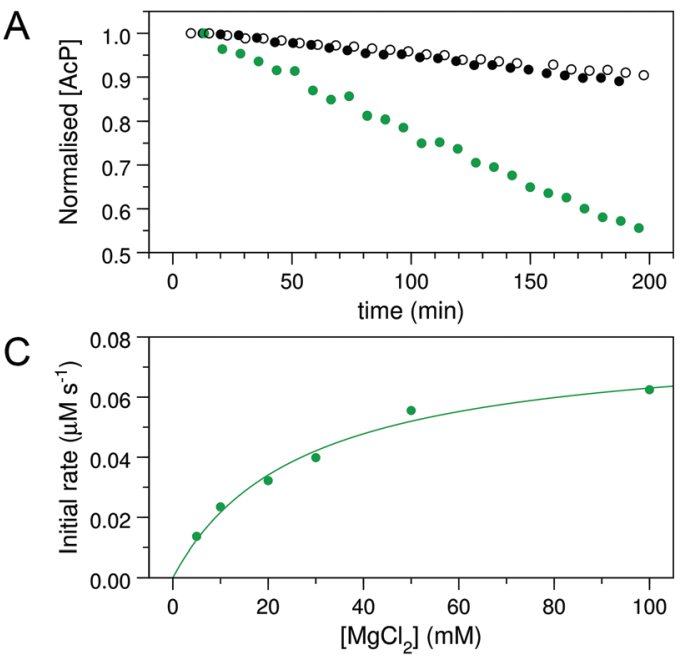
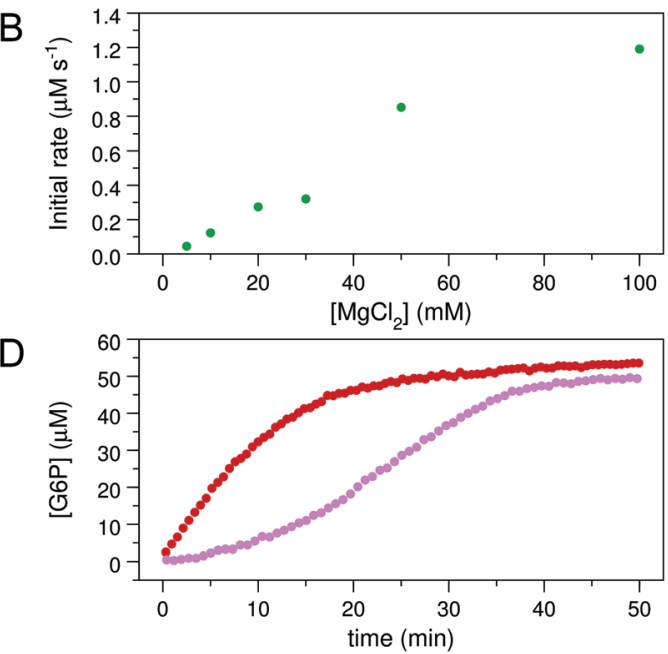

Fig. 3 Kinetic experiments involving $\beta P G M_{W T}$ and $\beta P G M_{D 170 N}$. (A) Effect of $\beta P G M_{W T}$ and $\beta P G M_{D 170 N}$ on the hydrolysis of AcP monitored using ${ }^{31} \mathrm{P}$ NMR time-course experiments. ACP hydrolysis profiles were derived from normalised peak intensities obtained from reactions containing 50 mM AcP in $200 \mathrm{mM} \mathrm{K}{ }^{+}$HEPES buffer ( $\mathrm{pH}$ 7.2) without $\mathrm{MgCl}_{2}$ (white circles) and separately in the presence of $300 \mu \mathrm{M} \beta P G M_{W T}$ (black circles) or presence of $300 \mu \mathrm{M} \beta P G M_{D 170 N}$ (green circles). (B and C) Activity of $\beta P G M_{D 170 N}$ with increasing $\mathrm{MgCl}_{2}$ concentration monitored using ${ }^{31} \mathrm{P} N M R$ time-course experiments. Samples contained $5 \mu M \beta P G M_{D 170 N}$ and $10 \mathrm{mM} \beta \mathrm{G} 1 \mathrm{P}$ in $200 \mathrm{mM} \mathrm{K}{ }^{+} \mathrm{HEPES}$ buffer $(\mathrm{pH} 7.2), 10 \%{ }^{2} \mathrm{H}_{2} \mathrm{O}(\mathrm{v} / \mathrm{v})$ and $1 \mathrm{mM} \mathrm{TSP}$ with increasing concentrations of $\mathrm{MgCl}_{2}(5,10,20,30,50,100 \mathrm{mM})$. The reactions were initiated by and timed from the addition of $20 \mathrm{mM}$ AcP. Initial rate measurements for (B) the Step 1 production of $\beta G 16 B P$ and $(C)$ the Step 2 production of G6P were obtained from linear least-squares fitting of normalised integral values of the ${ }^{31} \mathrm{P}$ resonances of $\beta G 16 B P$ and G6P present in the spectra. Subsequent fitting of the Step 2 initial rate values to eqn (1) using an in-house Python non-linear least squares fitting program yielded an apparent $K_{\mathrm{m}}\left(\mathrm{Mg}^{2+}\right)=27 \pm 4 \mathrm{mM}$. (D) Kinetic profiles for the conversion of $\beta$ G1P to G6P by $\beta P G M_{W T}$ monitored using a G6PDH coupled assay. Reactions were conducted in $200 \mathrm{mM} \mathrm{K}^{+} \mathrm{HEPES}$ buffer (pH 7.2) containing $5 \mathrm{mM} \mathrm{MgCl}_{2}, 1 \mathrm{mM} \mathrm{NAD}^{+}, 5 \mathrm{U} \mathrm{mL}^{-1} \mathrm{G} 6 \mathrm{PDH}, 50 \mu \mathrm{M} \beta \mathrm{G} 1 \mathrm{P}$ and $5 \mathrm{nM} \beta \mathrm{PGM}$ wT with either $1 \mu \mathrm{M}$ of the final $\beta \mathrm{G} 16 \mathrm{BP}$ product (red circles) or $8 \mathrm{mM}$ AcP (pink circles) as the phosphorylating agent. For clarity, only half of the acquired data points have been included. 

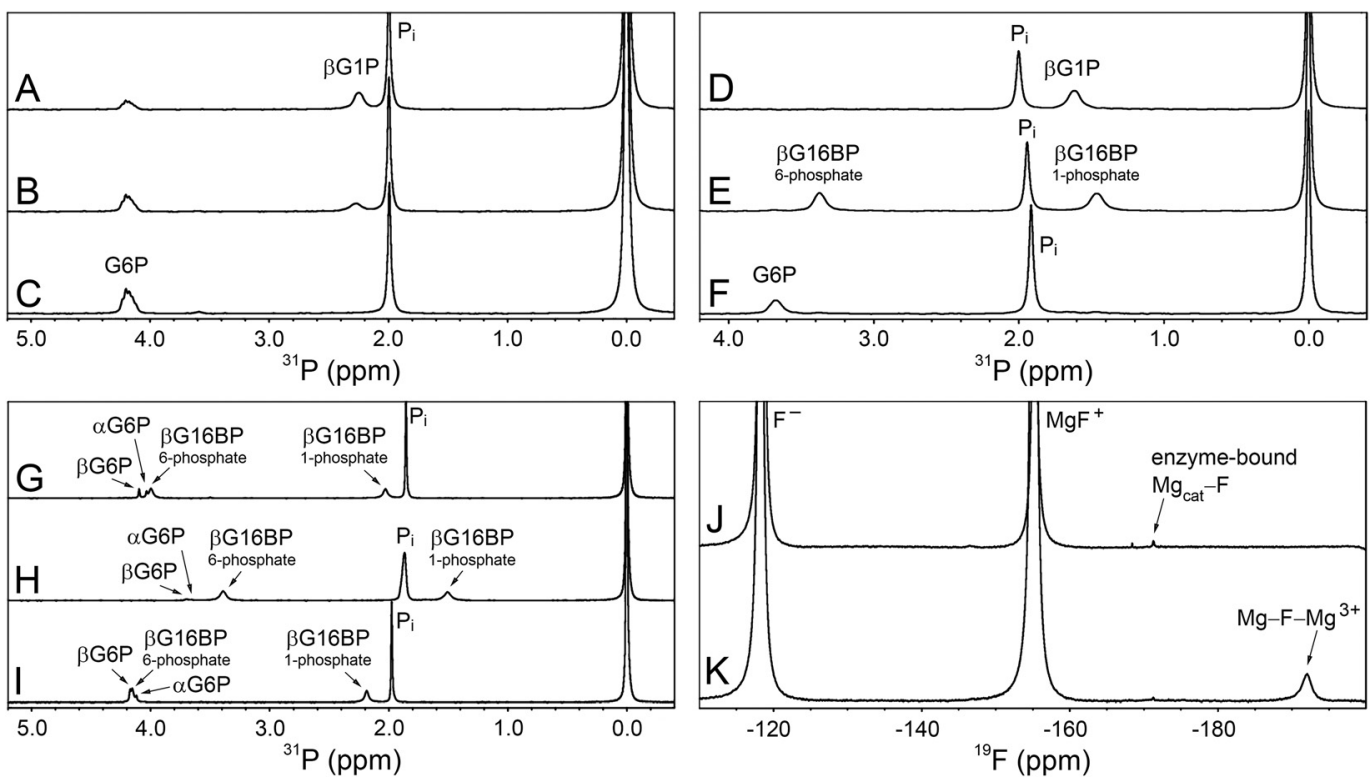

Fig. $4{ }^{31} \mathrm{P}$ and ${ }^{19} \mathrm{~F}$ NMR experiments involving $\beta P G M_{W T}$ and $\beta P G M_{D 170 N}$. (A-C) The $\beta P G M_{W T}$-catalysed conversion of $\beta G 1 P$ to G6P via $\beta G 16 B P$ in the absence of $\mathrm{Mg}^{2+}$ ions. (A) Reaction containing $300 \mu \mathrm{M} \beta \mathrm{PGM}_{\mathrm{WT}}$ and $10 \mathrm{mM} \beta \mathrm{G} 1 \mathrm{P}$ in $200 \mathrm{mM} \mathrm{K}^{+} \mathrm{HEPES}$ buffer (pH 7.2) without MgCl 2 , acquired $23 \mathrm{~min}$ after the addition of $50 \mathrm{mM}$ AcP. (B) Reaction after 42 min showing the presence of $\beta$ G1P and G6P. (C) Reaction after 72 min showing complete conversion of $\beta G 1 P$ to G6P. (D-F) The $\beta P G M_{D 170 N}$-catalysed conversion of $\beta G 1 P$ to G6P, together with the accumulation of $\beta G 16 B P$. (D) Reaction containing $20 \mu \mathrm{M} \beta \mathrm{PGM}_{\mathrm{D} 170 \mathrm{~N}}$ and $10 \mathrm{mM} \beta \mathrm{G} 1 \mathrm{P}$ in $200 \mathrm{mM} \mathrm{K}^{+} \mathrm{HEPES}$ buffer (pH 7.2) with $100 \mathrm{mM} \mathrm{MgCl}$, prior to the addition of $20 \mathrm{mM}$ AcP. (E) Reaction after 87 min showing the generation of $\beta G 16 B P$. (F) Reaction after 1179 min showing complete conversion of $\beta G 1 P$ to G6P. $(G-I)$ The $\beta P G M_{D 170 N^{-}}$catalysed conversion of $\beta G 1 P$ to $G 6 P$ together with the accumulation of $\beta G 16 B P$ under variable ion concentrations. (G) Reaction containing $400 \mu \mathrm{M} \beta \mathrm{PGM}_{\mathrm{D} 170 \mathrm{~N}}$ and $10 \mathrm{mM} \beta \mathrm{G} 1 \mathrm{P}$ in $200 \mathrm{mM} \mathrm{K} \mathrm{K}^{+} \mathrm{HEPES}$ buffer (pH 7.2) with $5 \mathrm{mM} \mathrm{MgCl}_{2}, 35 \mathrm{~min}$ after the addition of $20 \mathrm{mM}$ AcP. (H) Reaction containing $400 \mu \mathrm{M} \beta P G M_{D 170 \mathrm{~N}}$ and $10 \mathrm{mM} \beta \mathrm{G} 1 \mathrm{P}$ in $200 \mathrm{mM} \mathrm{K} \mathrm{HEPES}^{+}$buffer (pH 7.2) with $100 \mathrm{mM} \mathrm{MgCl}, 19 \mathrm{~min}$ after the addition of $20 \mathrm{mM}$ AcP. (I) Reaction containing $400 \mu \mathrm{M} \beta \mathrm{PGM}_{\mathrm{D} 170 \mathrm{~N}}$ and $10 \mathrm{mM} \beta \mathrm{G} 1 \mathrm{P}$ in $200 \mathrm{mM} \mathrm{K}^{+} \mathrm{HEPES}$ buffer (pH 7.2 ) with $5 \mathrm{mM}$ magnesium acetate and $200 \mathrm{mM} \mathrm{NaCl}, 36 \mathrm{~min}$ after the addition of $20 \mathrm{mM} \mathrm{ACP}$. The peak at 1.9-2.0 ppm in panels A-I corresponds to inorganic phosphate $\left(\mathrm{P}_{\mathrm{i}}\right)$, which is present in the stocks of both $\beta \mathrm{G} 1 \mathrm{P}$ and $\mathrm{AcP}$. ${ }^{31} \mathrm{P}$ chemical shifts were referenced to external $1 \mathrm{M} \mathrm{H}_{3} \mathrm{PO}_{4}=0.0 \mathrm{ppm}$, which was sealed inside a glass capillary and inserted into the sample NMR tubes. $(\mathrm{J}-\mathrm{K}){ }^{19} \mathrm{~F}$ NMR experiments involving $\beta P G M \mathrm{D}_{170 \mathrm{~N}}$ acquired in $200 \mathrm{mM} \mathrm{K}^{+} \mathrm{HEPES}$ buffer $(\mathrm{pH} 7.2)$ at $5{ }^{\circ} \mathrm{C}$. (J) A sample containing $0.5 \mathrm{mM} \beta P G M_{\mathrm{D} 170 \mathrm{~N}}$ with $5 \mathrm{mM} \mathrm{MgCl}, 10 \mathrm{mM} \mathrm{NaF}$ and $0.2 \mathrm{mM}$ deferoxamine shows an enzyme-bound ${ }^{19} \mathrm{~F}$ resonance $(-171 \mathrm{ppm})$ that corresponds to a $\mathrm{Mg}_{\text {cat }}-\mathrm{F}$ moiety. (K) A sample containing $0.5 \mathrm{mM} \beta \mathrm{PGM}_{\mathrm{D} 170 \mathrm{~N}}$ with $100 \mathrm{mM} \mathrm{MgCl}, 10 \mathrm{mM} \mathrm{NaF}$ and $0.2 \mathrm{mM}$ deferoxamine reveals that an increase in $\mathrm{Cl}^{-}$ion concentration results in a decrease in the peak intensity of the $\mathrm{Mg}_{\text {cat }}-\mathrm{F}$ moiety. Three free ${ }^{19} \mathrm{~F}$ species are present in solution: Free $\mathrm{F}^{-}(-118 \mathrm{ppm})$, free $\mathrm{MgF}^{+}(-155 \mathrm{ppm})$ and a free $\mathrm{Mg}-\mathrm{F}-\mathrm{Mg}^{3+}$ species $(-192 \mathrm{ppm})$, which have been assigned based on the partitioning behaviour between discrete species as the $\mathrm{MgCl}_{2}$ concentration is increased.

the enzyme $\mathrm{Mg}_{\text {cat }}$ site was engineered. In $\beta \mathrm{PGM}_{\mathrm{WT}}, \mathrm{Mg}_{\text {cat }}$ is coordinated octahedrally by a carboxylate oxygen atom of residue D8, a carboxylate oxygen atom of residue D170 and the carbonyl oxygen atom of residue D10, together with three water molecules. In $\beta \mathrm{PGM}_{\mathrm{WT}}{ }^{\mathrm{P}}$, one of the water molecules (water 3 ) is displaced by a phosphate oxygen atom of the D8 aspartyl phosphate moiety, creating bidentate coordination of $\mathrm{Mg}_{\text {cat }}$ in a sixmembered ring of atoms (Fig. 2). Point mutations involving residue D8 have been reported to result in the complete loss of measurable catalytic activity. ${ }^{19}$ Therefore, perturbation of $\mathrm{Mg}_{\text {cat }}$ was achieved through the generation of the $\mathrm{D} 170 \mathrm{~N}$ variant $\left(\beta \mathrm{PGM}_{\mathrm{D} 170 \mathrm{~N}}\right)$, where the carboxamide group of residue N170 retains an oxygen atom with which to coordinate $\mathrm{Mg}_{\text {cat }}$, but the sidechain is not charged. Accordingly, the reaction of $\beta \mathrm{PGM}_{\mathrm{D} 170 \mathrm{~N}}$ with $10 \mathrm{mM} \beta \mathrm{G} 1 \mathrm{P}$ and $20 \mathrm{mM}$ AcP in the presence of $100 \mathrm{mM} \mathrm{MgCl}_{2}$ was monitored using ${ }^{31} \mathrm{P}$ NMR time-course experiments and, in contrast to $\beta \mathrm{PGM}_{\mathrm{WT}}$, the $\beta \mathrm{G} 16 \mathrm{BP}$ intermediate was observed to accumulate to a level comparable with the initial $\beta$ G1P concentration (Fig. $4 \mathrm{D}$ and $\mathrm{E}$ ). The G6P product was only generated to a measurable extent once the AcP concentration had reduced significantly (Fig. 4F). Hence, perturbation of $\mathrm{Mg}_{\text {cat }}$ in $\beta \mathrm{PGM}_{\mathrm{D} 170 \mathrm{~N}}$ (in the presence of excess AcP) results in a substantial retardation of phosphorylation of $\beta \mathrm{PGM}_{\mathrm{D} 170 \mathrm{~N}}$ by $\beta$ G16BP (Step 2) with respect to phosphorylation of $\beta$ G1P by $\beta \mathrm{PGM}_{\mathrm{D} 170 \mathrm{~N}}{ }^{\mathrm{P}}$ (Step 1), therefore allowing $\beta \mathrm{G} 16 \mathrm{BP}$ to accumulate.

To investigate the source of the retardation of Step 2, glucose 6-phosphate dehydrogenase (G6PDH; EC 1.1.1.49) coupled assay experiments were conducted to assess the ability of $\beta \mathrm{PGM}_{\mathrm{D} 170 \mathrm{~N}}$ to bind and convert the substrates of Step 2 $(\beta \mathrm{G} 16 \mathrm{BP})$ and Step $1(\beta \mathrm{G} 1 \mathrm{P})$. Initial rate measurements were recorded at increasing concentrations of $\beta \mathrm{G} 16 \mathrm{BP}$, which revealed that $\beta \mathrm{PGM}_{\mathrm{D} 170 \mathrm{~N}}$ had an apparent $K_{\mathrm{m}}(\beta \mathrm{G} 16 \mathrm{BP})=150 \pm$ $13 \mu \mathrm{M}$ (Fig. $\mathrm{S} 1 \mathrm{~A} \dagger$ ). This value is 18 -fold weaker than that measured for $\beta \mathrm{PGM}_{\mathrm{WT}}\left(K_{\mathrm{m}}(\beta \mathrm{G} 16 \mathrm{BP})=8.5 \pm 0.3 \mu \mathrm{M}\right.$ (ref. 23)). Analogous experiments at increasing concentrations of $\beta \mathrm{G} 1 \mathrm{P}$ indicated that $\beta \mathrm{PGM}_{\mathrm{D} 170 \mathrm{~N}}$ had an apparent $K_{\mathrm{m}}(\beta \mathrm{G} 1 \mathrm{P})=$ $6.9 \pm 1.0 \mu \mathrm{M}$, which is similar in magnitude to the $K_{\mathrm{m}}(\beta \mathrm{G} 1 \mathrm{P})$ for $\beta \mathrm{PGM}_{\mathrm{WT}}\left(K_{\mathrm{m}}(\beta \mathrm{G} 1 \mathrm{P})=14.7 \pm 0.5 \mu \mathrm{M}\right.$ (ref. 12)). These experi- 
ments also demonstrated that a similar level of $\beta \mathrm{G} 1 \mathrm{P}$ inhibition was operating in $\beta \mathrm{PGM}_{\mathrm{D} 170 \mathrm{~N}}$ (apparent $K_{\mathrm{i}}(\beta \mathrm{G} 1 \mathrm{P})=$ $1540 \pm 170 \mu \mathrm{M})$ and $\beta \mathrm{PGM}_{\mathrm{WT}}\left(K_{\mathrm{i}}(\beta \mathrm{G} 1 \mathrm{P})=1510 \pm 100 \mu \mathrm{M}\right.$ (ref. 23)) (Fig. S1B $\dagger$ ). The $K_{\mathrm{m}}\left(\mathrm{Mg}^{2+}\right)$ value for the overall reaction of $\beta \mathrm{G} 1 \mathrm{P}$ to $\mathrm{G} 6 \mathrm{P}$ was also measured for $\beta \mathrm{PGM}_{\mathrm{D} 170 \mathrm{~N}}$ using increasing concentrations of $\mathrm{MgCl}_{2}$ (Fig. S2 $\dagger$ ). These experiments resulted in an apparent $K_{\mathrm{m}}\left(\mathrm{Mg}^{2+}\right)=690 \pm 110 \mu \mathrm{M}$, which is only 4 -fold weaker than that determined for $\beta \mathrm{PGM}_{\mathrm{WT}}$ using the same method (apparent $\left.K_{\mathrm{m}}\left(\mathrm{Mg}^{2+}\right)=180 \pm 40 \mu \mathrm{M}\right)$. Overall, at $1 \mathrm{mM} \beta \mathrm{G} 1 \mathrm{P}, 100 \mu \mathrm{M} \beta \mathrm{G} 16 \mathrm{BP}$ and $5 \mathrm{mM} \mathrm{MgCl}_{2}$ the observed rate constant for the overall reaction of $\beta \mathrm{G} 1 \mathrm{P}$ to G6P catalysed by $\beta \mathrm{PGM}_{\mathrm{D} 170 \mathrm{~N}}\left(k_{\mathrm{obs}}=3.0 \times 10^{-3} \mathrm{~s}^{-1}\right)$ is 79000 -fold smaller than that for $\beta \mathrm{PGM}_{\mathrm{WT}}\left(k_{\mathrm{obs}}=237 \mathrm{~s}^{-1}\right)$.

The observable accumulation of $\beta$ G16BP in the ${ }^{31} \mathrm{P}$ NMR spectra of the $\beta \mathrm{PGM}_{\mathrm{D} 170 \mathrm{~N}^{-}}$-catalysed reaction (Fig. $4 \mathrm{D}-\mathrm{F}$ ) presented an opportunity to measure the effects of $\mathrm{Mg}^{2+}$ ion concentration on Step 1 and Step 2 independently within the same experiment (Fig. 1), although it should be noted that kinetic parameters obtained using ${ }^{31} \mathrm{P}$ NMR methods and the G6PDH coupled assay differ significantly due to the effects of the different conditions employed. ${ }^{18,23}{ }^{31} \mathrm{P}$ NMR time-course experiments were therefore conducted at increasing concentrations of $\mathrm{MgCl}_{2}$ to measure simultaneously the initial rates of $\beta \mathrm{G} 16 \mathrm{BP}$ production in Step 1 and G6P production in Step 2 (Fig. 3B and C). The initial rates of $\beta$ G16BP production increased linearly with $\mathrm{MgCl}_{2}$ concentration and so could not be fitted to a Michaelis-Menten equation over the concentration range 5-100 mM (Fig. 3B), indicating that the affinity of $\beta \mathrm{PGM}_{\mathrm{D} 170 \mathrm{~N}}$ for $\mathrm{Mg}_{\text {cat }}$ in Step 1 is low. Extraction of the initial rates of G6P production in Step 2 resulted in an apparent $K_{\mathrm{m}}\left(\mathrm{Mg}^{2+}\right)=$ $27 \pm 4 \mathrm{mM}$ (Fig. 3C). These observations therefore reveal that $\beta$ G16BP accumulation can be greatly enhanced by using elevated concentrations of $\mathrm{Mg}^{2+}$ ions. For $\beta \mathrm{PGM}_{\mathrm{D} 170 \mathrm{~N}}$ at $5 \mathrm{mM}$ $\mathrm{MgCl}_{2}$, the initial rate of Step $1\left(k_{\text {obs }}=9.0 \times 10^{-3} \mathrm{~s}^{-1}\right)$ is only 3 -fold faster than that of Step $2\left(k_{\mathrm{obs}}=3.0 \times 10^{-3} \mathrm{~s}^{-1}\right)$, while at $100 \mathrm{mM} \mathrm{MgCl} 2$ Step $1\left(k_{\text {obs }}=0.24 \mathrm{~s}^{-1}\right)$ exceeds Step $2\left(k_{\text {obs }}=\right.$ $1.2 \times 10^{-2} \mathrm{~s}^{-1}$ ) by a factor of 20 (Fig. 3B, C and 4G, H). A control experiment employing elevated $\mathrm{NaCl}$ concentrations demonstrated that the increased initial rate of Step 1 at higher concentrations of $\mathrm{MgCl}_{2}$ is not caused by $\mathrm{Cl}^{-}$ions alone (Fig. 4I). Therefore, the $\mathrm{Mg}^{2+}$ ion concentration at which the production of $\beta$ G16BP is performed has a strong bearing on its yield.

Taken together, this analysis demonstrates that the D170N point mutation causes a pronounced retardation of Step 2 together with a more modest change to Step 1. The reduced apparent $K_{\mathrm{m}}$ value of $\beta \mathrm{PGM}_{\mathrm{D} 170 \mathrm{~N}}$ for $\beta \mathrm{G} 16 \mathrm{BP}$ is in line with this behaviour. However, the substantially different apparent $K_{\mathrm{m}}\left(\mathrm{Mg}^{2+}\right)$ values determined for Step 1 and Step 2 are not, which was surprising given the perturbation of the $\mathrm{Mg}_{\text {cat }}$ binding site in $\beta \mathrm{PGM}_{\mathrm{D} 170 \mathrm{~N}}$. One plausible explanation for these observations is that $\mathrm{a} \mathrm{Cl}^{-}$ion binds in the active site in substrate-free $\beta \mathrm{PGM}_{\mathrm{D} 170 \mathrm{~N}}$ to mitigate the loss of the negative charge resulting from the D170N point mutation. The presence of $\mathrm{a} \mathrm{Cl}^{-}$ion at the $\mathrm{Mg}_{\text {cat }}$ binding site would rescue the binding of $\mathrm{Mg}_{\text {cat }}$ but hamper the binding of $\beta \mathrm{G} 16 \mathrm{BP}$ and the approach of its phosphodianion to the carboxylate group of D8 in Step 2.
In contrast, $\mathrm{AcP}$ is able to generate $\mathrm{PPGM}_{\mathrm{D} 170 \mathrm{~N}}{ }^{\mathrm{P}}$ in a $\mathrm{Mg}_{\text {cat }}{ }^{-}$ independent manner (Fig. 1 and Fig. 3A) and the presence of the D8 aspartyl phosphate moiety will obviate the formation of the $\mathrm{Mg}_{\text {cat }}-\mathrm{Cl}$ moiety.

To obtain evidence for a putative $\mathrm{Mg}_{\text {cat }}$-halide moiety binding to substrate-free $\beta \mathrm{PGM}_{\mathrm{D} 170 \mathrm{~N}}, 10 \mathrm{mM} \mathrm{NaF}$ was added to substrate-free $\beta \mathrm{PGM}_{\mathrm{D} 170 \mathrm{~N}}$ containing $5 \mathrm{mM} \mathrm{MgCl}_{2}$ and ${ }^{19} \mathrm{~F}$ NMR experiments were recorded (Fig. 4J and $\mathrm{K}$ ). A $\beta \mathrm{PGM}_{\mathrm{D} 170 \mathrm{~N}}$-bound ${ }^{19} \mathrm{~F}$ species was observed with a chemical shift of $-171 \mathrm{ppm}$, which corresponds to an analogous peak seen for substrate-free $\beta \mathrm{PGM}_{\mathrm{WT}}$ acquired under similar conditions. ${ }^{24}$ Elevation to $100 \mathrm{mM} \mathrm{MgCl}$ did not result in increased saturation of $\mathrm{Mg}_{\text {cat }}$, but instead reduced the ${ }^{19} \mathrm{~F}$ peak integral to $80 \%$ of its size at $5 \mathrm{mM} \mathrm{MgCl}$, suggesting that at higher concentrations, $\mathrm{Cl}^{-}$ions are displacing the $\mathrm{F}^{-}$ion bound at the $\mathrm{Mg}_{\text {cat }}$ site (Fig. 4J and $\mathrm{K}$ ). In the experiment containing $100 \mathrm{mM}$ $\mathrm{MgCl}_{2}$, three free ${ }^{19} \mathrm{~F}$ species are present in solution that are separated by chemical shift differences of exactly $37 \mathrm{ppm}$. Free $\mathrm{F}^{-}$ $(-118 \mathrm{ppm})$ and free $\mathrm{MgF}^{+}(-155 \mathrm{ppm})$ have been assigned previously, ${ }^{24}$ whereas the peak resonating at $-192 \mathrm{ppm}$ is likely to be a free $\mathrm{Mg}-\mathrm{F}-\mathrm{Mg}^{3+}$ species, based on the partitioning behaviour between discrete species as the $\mathrm{MgCl}_{2}$ concentration is increased. Comparison of the chemical shifts of the $\beta \mathrm{PGM}_{\mathrm{D} 170 \mathrm{~N}^{-}}$ bound ${ }^{19} \mathrm{~F}$ species with those of the three free species suggests that it is closer in identity to $\mathrm{MgF}^{+}$. Therefore, the primary candidate for such an enzyme-bound species is a $\mathrm{Mg}_{\text {cat }}-\mathrm{F}$ moiety, which in turn provides supporting evidence for the binding of a $\mathrm{Mg}_{\text {cat }}-\mathrm{Cl}$ moiety to substrate-free $\beta \mathrm{PGM}_{\mathrm{D} 170 \mathrm{~N}}$ that would consequently play a role in the retardation of Step 2 relative to Step 1.

The large-scale generation of $\beta \mathrm{G} 16 \mathrm{BP}$ by the $\beta \mathrm{PGM}_{\mathrm{D} 170 \mathrm{~N}^{-}}{ }^{-\mathrm{cat}}-$ alysed reaction at high concentrations of $\mathrm{MgCl}_{2}$ thus presented an opportunity for harvesting significant quantities of this valuable compound and so a robust production protocol was devised. Recombinant $\beta \mathrm{PGM}_{\mathrm{D} 170 \mathrm{~N}}$ is overexpressed in high yields from Escherichia coli BL21(DE3) cells (>100 $\mathrm{mg} \mathrm{L}^{-1}$ ) using routine culture techniques and is readily purified using a two-step protocol involving ion-exchange chromatography followed by a size-exclusion chromatography step. $\beta \mathrm{PGM}_{\mathrm{D} 170 \mathrm{~N}}$ can be stored at $-20{ }^{\circ} \mathrm{C}$ for long periods and responds well to multiple freeze-thaw cycles, meaning that once purified, a batch of enzyme can be used for numerous $\beta$ G16BP preparations. In order to characterise $\beta \mathrm{PGM}_{\mathrm{D} 170 \mathrm{~N}}$ further, ${ }^{1} \mathrm{H}^{15} \mathrm{~N}$-TROSY NMR spectra were recorded using samples of ${ }^{15} \mathrm{~N}-\beta \mathrm{PGM} \mathrm{D}_{\mathrm{D} 170 \mathrm{~N}}$ and ${ }^{15} \mathrm{~N}-\beta \mathrm{PGM}_{\mathrm{WT}}$. Comparison of the spectra revealed that $\beta \mathrm{PGM}_{\mathrm{D} 170 \mathrm{~N}}$ has a similar solution behaviour and overall protein fold to $\beta \mathrm{PGM}_{\mathrm{WT}}$ (Fig. S3†). The slow-exchange behaviour that arises in $\beta \mathrm{PGM}_{\mathrm{WT}}$ from cis-trans proline isomerisation at the K145-P146 peptide bond is also observable in $\beta \mathrm{PGM}_{\mathrm{D} 170 \mathrm{~N}}{ }^{23}$ Notably, around 15 peaks are present for $\beta \mathrm{PGM}_{\mathrm{D} 170 \mathrm{~N}}$ that are absent in the spectrum of $\beta \mathrm{PGM}_{\mathrm{WT}}$. These additional peaks indicate that a backbone conformational exchange process, occurring on the millisecond timescale in $\beta \mathrm{PGM}_{\mathrm{WT}}$, has been abolished in $\beta \mathrm{PGM}_{\mathrm{D} 170 \mathrm{~N}}{ }^{23}$

To assess the stability of $\beta_{\mathrm{PGM}} \mathrm{D}_{\mathrm{D} 170 \mathrm{~N}}$ and to check for timedependent reversion to $\beta \mathrm{PGM}_{\mathrm{WT}}$ by deamidation, ${ }^{25}$ a sample of $\beta \mathrm{PGM}_{\mathrm{D} 170 \mathrm{~N}}$ was incubated at $25{ }^{\circ} \mathrm{C}$ for $48 \mathrm{~h}$ and both 
${ }^{1} \mathrm{H}^{15} \mathrm{~N}$-TROSY NMR spectra and ${ }^{31} \mathrm{P}$ NMR time-course experiments were acquired every $24 \mathrm{~h}$. A comparison of ${ }^{1} \mathrm{H}^{15} \mathrm{~N}$-TROSY spectra recorded for $\beta \mathrm{PGM}_{\mathrm{D} 170 \mathrm{~N}}$ preincubated at $25{ }^{\circ} \mathrm{C}$ for $0 \mathrm{~h}$ and $48 \mathrm{~h}$ shows a near-identical correspondence of peaks indicating that the incubation process has a negligible effect on the integrity of $\beta \mathrm{PGM}_{\mathrm{D} 170 \mathrm{~N}}$ (Fig. S4A $\dagger$ ). In comparisons of $\beta \mathrm{PGM}_{\mathrm{D} 170 \mathrm{~N}}$ and $\beta \mathrm{PGM}_{\mathrm{WT}}{ }^{1} \mathrm{H}^{15} \mathrm{~N}$-TROSY spectra, the absence of observable $\beta \mathrm{PGM}_{\mathrm{WT}}$ peaks in the $\beta \mathrm{PGM}_{\mathrm{D} 170 \mathrm{~N}}$ spectra indicates that reversion of $\beta P G M_{D 170 N}$ to $\beta P G M_{W T}$ through deamidation is not a process that occurs readily under these sample conditions (Fig. S4B and $\mathrm{C}^{\dagger}$ ). Analysis of the ${ }^{31} \mathrm{P}$ NMR time-course experiments for the equilibration of $10 \mathrm{mM} \beta \mathrm{G} 1 \mathrm{P}$ with G6P catalysed by $\beta \mathrm{PGM}_{\mathrm{D} 170 \mathrm{~N}}$ (preincubated at $25{ }^{\circ} \mathrm{C}$ for $0 \mathrm{~h}, 24 \mathrm{~h}$ and $48 \mathrm{~h}$ ) demonstrates a consistent behaviour of $\beta \mathrm{G} 16 \mathrm{BP}$ production followed by conversion to G6P as product with no change in $k_{\text {obs }}$, further confirming the stability of $\beta \mathrm{PGM}_{\mathrm{D} 170 \mathrm{~N}}$ (Fig. S5A $\dagger$ ).

To mimic the effect of $\beta \mathrm{PGM}_{\mathrm{D} 170 \mathrm{~N}}$ reversion to $\beta \mathrm{PGM}_{\mathrm{WT}}$ through deamidation, a control ${ }^{31} \mathrm{P}$ NMR time-course experiment was also conducted using a sample of $\beta \mathrm{PGM}_{\mathrm{D} 170 \mathrm{~N}}$ that had been spiked with $0.1 \% \beta \mathrm{PGM}_{\mathrm{WT}}$ (Fig. S5B $\dagger$ ). The kinetic profile shows an initial burst of $\mathrm{G} 6 \mathrm{P}$ production by $\beta \mathrm{PGM}_{\mathrm{WT}}$ together with a decrease in the ratio of the $\beta \mathrm{G} 16 \mathrm{BP}$ concentration at its maximum $\left(\beta \mathrm{G}_{16 \mathrm{BP}}\right.$ max $)$ to the concentration of G6P at its maximum (G6P $\left.\mathrm{P}_{\max }\right)$. The ${ }^{31} \mathrm{P}$ NMR time-course experiments testing $\beta \mathrm{PGM}_{\mathrm{D} 170 \mathrm{~N}}$ stability revealed no burst of G6P production nor any change in either $k_{\text {obs }}$ or the $\beta \mathrm{G} 16 \mathrm{BP} \mathrm{P}_{\max }: \mathrm{G} \mathrm{P}_{\max }$ ratio. Together, these results indicate that $\beta \mathrm{PGM}_{\mathrm{D} 170 \mathrm{~N}}$ does not undergo detectable deamidation to $\beta \mathrm{PGM}_{\mathrm{WT}}$ and is stable at $25^{\circ} \mathrm{C}$ over a 48 -hour time frame.
${ }^{31} \mathrm{P}$ NMR time-course experiments were used to monitor the $\beta \mathrm{PGM}_{\mathrm{D} 170 \mathrm{~N}^{-}}$-catalysed conversion of $\beta \mathrm{G} 1 \mathrm{P}$ to G6P to determine the optimal point at which to harvest $\beta$ G16BP. In a representative reaction (see Materials and Methods) the $\beta$ G16BP concentration reached a maximum after $265 \mathrm{~min}$ at $25{ }^{\circ} \mathrm{C}$. Following quenching of the reaction at this point, and removal of $\beta \mathrm{PGM}_{\mathrm{D} 170 \mathrm{~N}}$, the solution was found to contain $\beta \mathrm{G} 16 \mathrm{BP}$ alongside contaminants that included significant amounts of $\beta$ G1P, G6P and inorganic phosphate $\left(\mathrm{P}_{\mathrm{i}}\right)$, in a ratio of $1: 0.07: 0.2: 3.9$, respectively. As substrates of $\beta$ PGM, these phosphorylated impurities are undesirable, therefore the solution was subjected to a barium salt precipitation and ionexchange protocol to obtain the sodium salt of $\beta \mathrm{G} 16 \mathrm{BP}$ with high purity. Barium salts of phosphate species are relatively insoluble, ${ }^{26}$ and the difference in relative solubility of the $\beta$ G16BP barium salt compared with those of $\beta$ G1P and G6P was exploited to enable purification. ${ }^{27-29}$

To confirm the identity and assess the purity of the final $\beta$ G16BP product, a sample of the fine powder was analysed using ${ }^{1} \mathrm{H},{ }^{13} \mathrm{C}$ and ${ }^{31} \mathrm{P}$ NMR experiments (Fig. 5A-D). The identity of the resulting compound was established to be $\beta \mathrm{G} 16 \mathrm{BP}$ by comparison of ${ }^{1} \mathrm{H}$ and ${ }^{13} \mathrm{C}$ chemical shifts with previously reported values. ${ }^{12}$ Glucose and maltose contaminants were identified in the sample using ${ }^{1} \mathrm{H}$ chemical shifts and scalar coupling constants (BMRB: bmse000015, BMRB: bmse000017). Based on integral values of the anomeric proton signals and of the phosphorus signals in quantitative ${ }^{1} \mathrm{H}$ and ${ }^{31} \mathrm{P} N M R$ spectra, the $\beta$ G16BP concentration was determined to be $67 \mathrm{mM}$, which represented $98 \%$ of the total phosphorylated glucosaccharide components and $72 \%$ of the total glucosac-
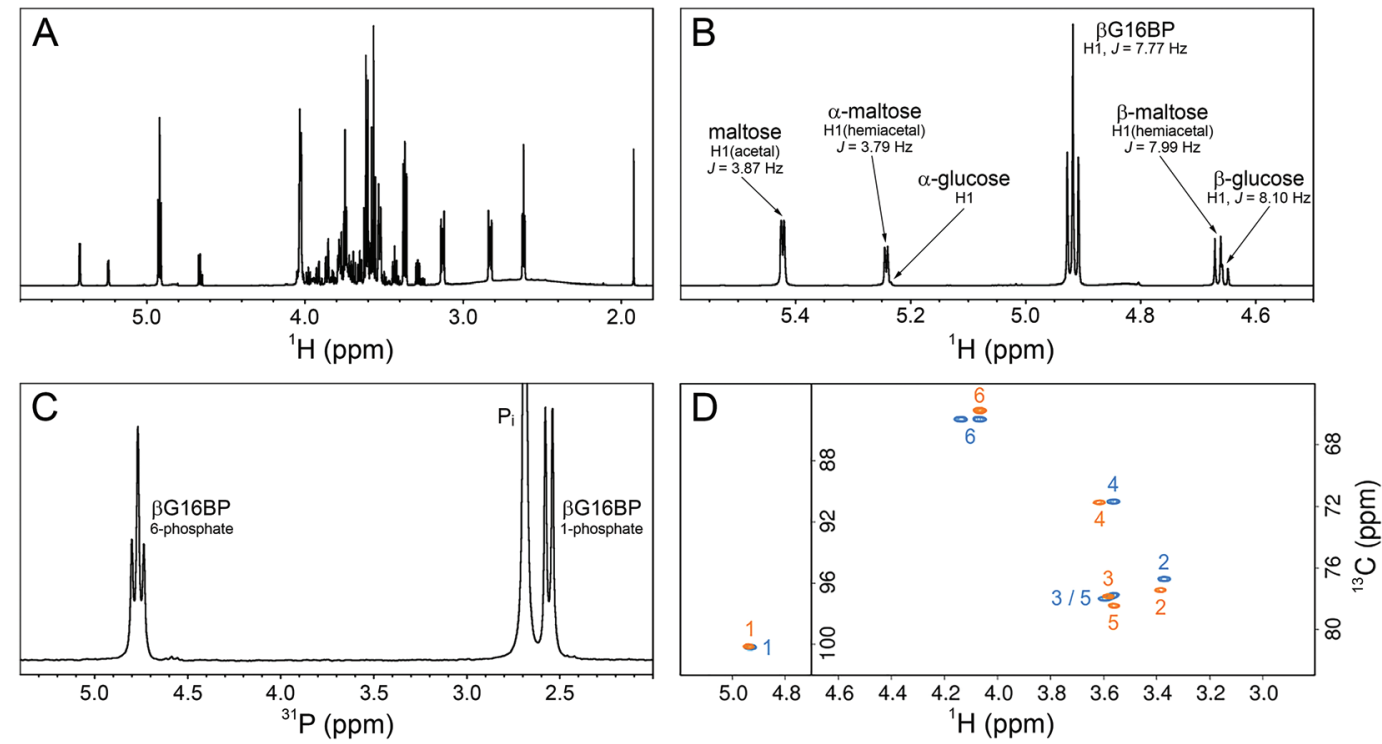

Fig. 5 NMR experiments recorded on a sample of the final $\beta$ G16BP product, purified following its production by $\beta$ PGM $M_{D 170 N}$ and prepared in $100 \%$ ${ }^{2} \mathrm{H}_{2} \mathrm{O}$. (A) ${ }^{1} \mathrm{H}$ spectrum showing $\beta G 16 B P$ and other glucosaccharide species present in the sample. (B) A region of the ${ }^{1} \mathrm{H}$ spectrum showing the anomeric proton glucosaccharide signals, together with their assignments. (C) ${ }^{31} \mathrm{P}$ spectrum showing the two phosphorus signals of $\beta \mathrm{G} 16 \mathrm{BP}$ (6-phosphate, $4.76 \mathrm{ppm}$ (triplet) and 1-phosphate, $2.55 \mathrm{ppm}$ (doublet)) and the signal corresponding to inorganic phosphate ( $\mathrm{P}_{\mathrm{i}}, 2.70 \mathrm{ppm}($ singlet), truncated for clarity). (D) Natural abundance ${ }^{1} \mathrm{H}^{13} \mathrm{C}-\mathrm{HSQC}$ spectra comparing the final $\beta \mathrm{G} 16 \mathrm{BP}$ product (orange) with chemically synthesised $\beta$ G16BP (blue). ${ }^{12}$ Peaks are labelled with carbon ring atom assignments. 
charide components present in the final sample. $\beta \mathrm{G} 1 \mathrm{P}, \mathrm{G} 6 \mathrm{P}$ and glucose comprised $<1 \%, 1 \%$ and $3 \%$, respectively, of the total glucosaccharide content. Maltose was present at a greater concentration in the sample $(24 \%)$, but as a bystander in the reactions of $\beta$ PGM, and not known to bind to phosphomannomutase 2, this contamination is unlikely to be problematic for users. $\mathrm{P}_{\mathrm{i}}$ was also present at a concentration 2.9-fold higher than that of $\beta \mathrm{G} 16 \mathrm{BP}$. The glucose, maltose and $\mathrm{P}_{\mathrm{i}}$ components, which were carried through into the final $\beta$ G16BP product, are contaminants derived from the enzymatic synthesis of $\beta \mathrm{G} 1 \mathrm{P}$ and would otherwise not be present if a purer source of $\beta \mathrm{G} 1 \mathrm{P}$ were used. Residual HEPES buffer and acetate were also present as minor contaminants. The final yield for the $\beta \mathrm{PGM}_{\mathrm{D} 170 \mathrm{~N}^{-}}$-catalysed conversion of $\beta \mathrm{G} 1 \mathrm{P}$ to $\beta \mathrm{G} 16 \mathrm{BP}$ was $33.6 \%$ and the yield for the overall conversion of maltose to $\beta \mathrm{G} 16 \mathrm{BP}$ was $7.7 \%$. Since the equilibrium for the enzymatic conversion of maltose to $\beta \mathrm{G} 1 \mathrm{P}$ lies in favour of maltose, conducting the reactions for the maltose phosphorylase synthesis of $\beta \mathrm{G} 1 \mathrm{P}$ and the $\beta P_{\text {PGM }} M_{\mathrm{D} 170 \mathrm{~N}}$ synthesis of $\beta \mathrm{G} 16 \mathrm{BP}$ in a one-pot system is likely to lead to higher $\beta$ G16BP yields. The removal of $\beta$ G1P by $\beta \mathrm{PGM}_{\mathrm{D} 170 \mathrm{~N}}$ would drive the maltose reaction to produce more $\beta$ G1P, which in turn would result in a greater overall yield of $\beta$ G16BP. This approach has been demonstrated previously for the protocol involving maltose phosphorylase and phosphofructokinase. ${ }^{17}$ To demonstrate the biochemical effectiveness of the final $\beta \mathrm{G} 16 \mathrm{BP}$ product at activating $\beta \mathrm{PGM}_{\mathrm{WT}}$, a kinetic experiment was conducted using the G6PDH coupled assay. $\beta \mathrm{PGM}_{\mathrm{WT}}$ was mixed with the $\beta \mathrm{G} 1 \mathrm{P}$ substrate and activated using either $1 \mu \mathrm{M} \beta \mathrm{G} 16 \mathrm{BP}$ (produced using $\beta \mathrm{PGM}_{\mathrm{D} 170 \mathrm{~N}}$ ) or $8 \mathrm{mM} \mathrm{AcP}$ as the phosphorylating agent. The kinetic profile obtained was linear for the $\beta \mathrm{G} 16 \mathrm{BP}$-containing reaction, but exhibited a lag phase when AcP was used (Fig. 3D). As $\beta$ G16BP is the only phosphorylating agent known to induce linear initial kinetics in $\beta \mathrm{PGM},{ }^{23}$ this experiment provided a clear demonstration of the activity of the final $\beta$ G16BP product.

\section{Conclusions}

The successful manipulation of $\beta$ PGM behaviour to facilitate $\beta$ G16BP production is a demonstration of how detailed structural and mechanistic knowledge of an enzyme can lead to novel engineering strategies. Specifically, the modification of the metal binding site of the enzyme dramatically increases the steady state concentration of its reactive intermediate. This highlights the transformative potential that enzymes have within chemical industries and vindicates the intensive study of these useful biomolecules.

\section{Materials and methods}

\section{Reagents}

Unless stated otherwise, reagents were purchased from SigmaAldrich, Fischer Scientific, Alfa Aesar and VWR. Isotopically enriched ${ }^{15} \mathrm{NH}_{4} \mathrm{Cl}$ was purchased from CortecNet.

\section{Gene sequence for $\boldsymbol{\beta P G M}_{\mathrm{D} 170 \mathrm{~N}}$}

CATATGTTTAAAGCAGTATTGTTTGATTTAGATGGTGTAATTA CAGATACCGCAGAGTATCATTTTAGAGCTTGGAAAGCTTTGG CTGAAGAAATTGGCATTAATGGTGTTGACCGCCAATTTAATG AGCAATTAAAAGGGGTCTCACGAGAAGACTCGCTTCAGAAAA TTCTAGATTTAGCTGATAAAAAAGTATCAGCTGAGGAATTTAA AGAACTTGCTAAGAGAAAAAATGATAACTATGTGAAAATGATT CAGGATGTGTCGCCAGCCGATGTCTATCCTGGAATTTTACAAT TACTCAAAGATTTACGTTCAAATAAAATCAAAATTGCTTTAGCG TCGGCTTCTAAGAATGGTCCATTTTTATTAGAGAGAATGAATTT AACTGGATATTTTGATGCAATTGCTGATCCGGCTGAAGTTGCAG CATCAAAACCAGCACCAGATATTTTTATTGCAGCAGCACATGCA GTGGGTGTTGCCCCCTCTGAATCAATTGGGTTAGAGAATTCTCA AGCTGGAATTCAAGCCATCAAAGATTCAGGGGCTTTACCAATTG GTGTAGGGCGCCCAGAAGATTTGGGAGATGATATCGTCATTGT GCCTGATACTTCACACTATACATTAGAATTTTTGAAAGAAGTTTG GCTTCAAAAGCAAAAATAACTCGAG.

\section{$\beta$ PGM expression and purification}

The $\beta$ PGM $M_{\mathrm{D} 170 \mathrm{~N}}$ gene sequence was created by modifying the pgmB gene (encoding the $\beta \mathrm{PGM}_{\mathrm{WT}}$ enzyme) from Lactococcus lactis (subspecies lactis IL1403) (NCBI: 1114041). The $\beta \mathrm{PGM}_{\mathrm{D} 170 \mathrm{~N}}$ gene was generated and cloned by GenScript into a pET22b $(+)$ vector. The $\beta \mathrm{PGM}_{\mathrm{WT}}$ and $\beta \mathrm{PGM}_{\mathrm{D} 170 \mathrm{~N}}$ plasmids were transformed into Escherichia coli BL21(DE3) cells and grown using ${ }^{15} \mathrm{~N}$ isotopically enriched M9 minimal media. ${ }^{30}$ Cells were grown to an $\mathrm{OD}_{600}$ of 0.6 at $37{ }^{\circ} \mathrm{C}$ and overexpression was induced with $0.5 \mathrm{mM}$ (final concentration) isopropyl $\beta$-D-1-thiogalactopyranoside (IPTG) before a 16-hour incubation at $25{ }^{\circ} \mathrm{C}$ and centrifugation (Sigma Model 3-15; $9000 \mathrm{rpm}$ for $10 \mathrm{~min}$ ) to harvest the cells. The $\beta \mathrm{PGM}_{\mathrm{WT}}$ and $\beta \mathrm{PGM}_{\mathrm{D} 170 \mathrm{~N}}$ proteins were purified using the following protocol. The cell pellet was resuspended in ice-cold standard buffer (50 mM K ${ }^{+}$HEPES buffer ( $\mathrm{pH} 7.2$ ), $5 \mathrm{mM} \mathrm{MgCl}_{2}, 2 \mathrm{mM}$ $\mathrm{NaN}_{3}, 1 \mathrm{mM}$ EDTA) containing a cOmplete protease inhibitor cocktail. The cell suspension was sonicated on ice for $6 \times 20 \mathrm{~s}$ pulses separated by $60 \mathrm{~s}$ intervals. The cell lysate was separated from the insoluble cell debris using centrifugation (Beckman Coulter Avanti centrifuge, Rotor: JA-25-50) at $20000 \mathrm{rpm}$ for $30 \mathrm{~min}$ at $4{ }^{\circ} \mathrm{C}$. The soluble fraction was loaded onto a DEAE-Sepharose anion-exchange column connected to an ÄKTA Prime purification system, which had been washed previously with $1 \mathrm{M} \mathrm{NaOH}$ and $6 \mathrm{M}$ guanidinium chloride and equilibrated with 5 column volumes of standard buffer. Bound proteins were eluted using a gradient of 0 to $50 \%$ standard buffer supplemented with $1 \mathrm{M} \mathrm{NaCl}$ over $300 \mathrm{~mL}$. Fractions containing $\beta$ PGM were identified using SDS-PAGE and were concentrated to a 5-10 $\mathrm{mL}$ volume using centrifugation in a Vivaspin $(10 \mathrm{kDa}$ molecular weight cut off; Sartorius) at $4500 \mathrm{rpm}$ and $4{ }^{\circ} \mathrm{C}$ (Thermo Scientific Heraeus Labofuge $400 \mathrm{R})$. The concentrated protein sample was loaded onto a pre-packed Hiload 26/600 Superdex 75 sizeexclusion column connected to an ÄKTA Prime purification system, which had been washed previously with degassed $1 \mathrm{M}$ 
$\mathrm{NaOH}$ and equilibrated with 3 column volumes of degassed standard buffer supplemented with $1 \mathrm{M} \mathrm{NaCl}$. Following elution, the fractions containing $\beta$ PGM were checked for purity and were pooled and buffer-exchanged into standard buffer for $\beta$ PGM ${ }_{\mathrm{WT}}$ and standard buffer containing $50 \mathrm{mM} \mathrm{MgCl}_{2}$ for $\beta \mathrm{PGM}_{\mathrm{D} 170 \mathrm{~N}} \cdot \mathrm{Mg}_{\text {cat }}$-free $\beta \mathrm{PGM}_{\mathrm{WT}}$ and $\mathrm{Mg}_{\text {cat }}$-free $\beta \mathrm{PGM}_{\mathrm{D} 170 \mathrm{~N}}$ were prepared by buffer-exchanging into standard buffer without $\mathrm{MgCl}_{2}$. The final protein samples were concentrated using a Vivaspin (10 kDa molecular weight cut off; Sartorius) to a $1 \mathrm{mM}$ concentration, as measured by Nanodrop One ${ }^{\mathrm{C}}$ (Thermo Scientific) ( $\beta$ PGM molecular weight $=24.2 \mathrm{kDa}, \varepsilon_{280}=$ $19940 \mathrm{M}^{-1} \mathrm{~cm}^{-1}$ ), and were stored at $-20^{\circ} \mathrm{C}$.

\section{NMR spectroscopy}

All NMR spectra were acquired at $298 \mathrm{~K}$, unless stated otherwise. ${ }^{31} \mathrm{P}$ NMR time-course experiments were acquired using a Bruker $500 \mathrm{MHz}$ Avance II spectrometer (operating at 202.456 $\mathrm{MHz}$ for ${ }^{31} \mathrm{P}$ ) equipped with a $5 \mathrm{~mm}$ room-temperature broadband probe and running TopSpin version 3.5. Onedimensional experiments consisting of 256 transients were recorded with a recycle delay of $1 \mathrm{~s}$ with proton-phosphorus decoupling and took 479.4 s to acquire. Where stated, experiments were acquired without phosphorus decoupling and took $370.4 \mathrm{~s}$ to record. For the AcP hydrolysis experiments, no proton-phosphorus decoupling was used and samples contained $50 \mathrm{mM}$ AcP in $200 \mathrm{mM} \mathrm{K}^{+}$HEPES buffer (pH 7.2), 10\% ${ }^{2} \mathrm{H}_{2} \mathrm{O}(\mathrm{v} / \mathrm{v})$ and $1 \mathrm{mM}$ trimethylsilyl propionate (TSP) without $\mathrm{MgCl}_{2}$, together with either $300 \mu \mathrm{M} \beta \mathrm{PGM}_{\mathrm{WT}}$ or $300 \mu \mathrm{M}$ $\beta \mathrm{PGM}_{\mathrm{D} 170 \mathrm{~N}}$. For the reactions involving the $\beta \mathrm{PGM}$-catalysed conversion of $\beta \mathrm{G} 1 \mathrm{P}$ to G6P, samples contained: $300 \mu \mathrm{M}$ $\beta \mathrm{PGM}_{\mathrm{WT}}, 10 \mathrm{mM} \beta \mathrm{G} 1 \mathrm{P}$ and $50 \mathrm{mM}$ AcP in $200 \mathrm{mM} \mathrm{K}^{+}$HEPES buffer ( $\mathrm{pH} 7.2$ ), $10 \%{ }^{2} \mathrm{H}_{2} \mathrm{O}(\mathrm{v} / \mathrm{v})$ and $1 \mathrm{mM}$ TSP without $\mathrm{MgCl}_{2}$ and with no proton-phosphorus decoupling used; $20 \mu \mathrm{M}$ $\beta \mathrm{PGM}_{\mathrm{D} 170 \mathrm{~N}}, 10 \mathrm{mM} \beta \mathrm{G} 1 \mathrm{P}$ and $20 \mathrm{mM}$ AcP in $200 \mathrm{mM} \mathrm{K}$ HEPES buffer ( $\mathrm{pH} 7.2), 10 \%{ }^{2} \mathrm{H}_{2} \mathrm{O}(\mathrm{v} / \mathrm{v})$ and $1 \mathrm{mM}$ TSP with $100 \mathrm{mM} \mathrm{MgCl}_{2}$ and with no proton-phosphorus decoupling used; $400 \mu \mathrm{M} \beta \mathrm{PGM}_{\mathrm{D} 170 \mathrm{~N}}, 10 \mathrm{mM} \beta \mathrm{G} 1 \mathrm{P}$ and $20 \mathrm{mM} \mathrm{AcP}$ in $200 \mathrm{mM} \mathrm{K}{ }^{+}$HEPES buffer ( $\left.\mathrm{pH} 7.2\right), 10 \%{ }^{2} \mathrm{H}_{2} \mathrm{O}(\mathrm{v} / \mathrm{v})$ and $1 \mathrm{mM}$ TSP with $5 \mathrm{mM} \mathrm{MgCl}_{2} ; 400 \mu \mathrm{M} \beta \mathrm{PGM}_{\mathrm{D} 170 \mathrm{~N}}, 10 \mathrm{mM} \beta \mathrm{G} 1 \mathrm{P}$ and $20 \mathrm{mM}$ AcP in $200 \mathrm{mM} \mathrm{K}{ }^{+}$HEPES buffer $(\mathrm{pH} 7.2), 10 \%{ }^{2} \mathrm{H}_{2} \mathrm{O}$ (v/v) and $1 \mathrm{mM}$ TSP with $100 \mathrm{mM} \mathrm{MgCl}_{2} ; 400 \mu \mathrm{M} \beta \mathrm{PGM}_{\mathrm{D} 170 \mathrm{~N}}$, $10 \mathrm{mM} \beta \mathrm{G} 1 \mathrm{P}$ and $20 \mathrm{mM}$ AcP in $200 \mathrm{mM} \mathrm{K} \mathrm{K}^{+}$HEPES buffer ( $\mathrm{pH} 7.2$ ), $10 \%{ }^{2} \mathrm{H}_{2} \mathrm{O}(\mathrm{v} / \mathrm{v})$ and $1 \mathrm{mM}$ TSP with $5 \mathrm{mM}$ magnesium acetate and $200 \mathrm{mM} \mathrm{NaCl}$. For the $\beta \mathrm{PGM}_{\mathrm{D} 170 \mathrm{~N}}$ stability measurements, samples contained $200 \mu \mathrm{M} \beta \mathrm{PGM}_{\mathrm{D} 170 \mathrm{~N}}$ (preincubated at $25{ }^{\circ} \mathrm{C}$ either for $0 \mathrm{~h}, 24 \mathrm{~h}$ or $48 \mathrm{~h}$ ), $10 \mathrm{mM} \beta \mathrm{G} 1 \mathrm{P}$ and $20 \mathrm{mM}$ AcP in $200 \mathrm{mM} \mathrm{K}{ }^{+}$HEPES buffer ( $\mathrm{pH} 7.2$ ), $10 \%{ }^{2} \mathrm{H}_{2} \mathrm{O}$ (v/v) and $1 \mathrm{mM}$ TSP with $100 \mathrm{mM} \mathrm{MgCl}_{2}$. For the experiment representative of $0.1 \%$ reversion of $\beta \mathrm{PGM}_{\mathrm{D} 170 \mathrm{~N}}$ to $\beta \mathrm{PGM}_{\mathrm{WT}}$ through deamidation, the sample contained $200 \mu \mathrm{M}$ $\beta \mathrm{PGM}_{\mathrm{D} 170 \mathrm{~N}}$ and $200 \mathrm{nM} \beta \mathrm{PGM}_{\mathrm{WT}}, 10 \mathrm{mM} \beta \mathrm{G} 1 \mathrm{P}$ and $20 \mathrm{mM}$ AcP in $200 \mathrm{mM} \mathrm{K}^{+}$HEPES buffer (pH 7.2), 10\% ${ }^{2} \mathrm{H}_{2} \mathrm{O}(\mathrm{v} / \mathrm{v})$ and $1 \mathrm{mM}$ TSP with $100 \mathrm{mM} \mathrm{MgCl}_{2}$. To measure apparent $K_{\mathrm{m}}\left(\mathrm{Mg}^{2+}\right)$ values for the Step 1 production of $\beta$ G16BP and the Step 2 production of $\mathrm{G} 6 \mathrm{P}$, samples contained $5 \mu \mathrm{M}$ $\beta \mathrm{PGM}_{\mathrm{D} 170 \mathrm{~N}}, 10 \mathrm{mM} \beta \mathrm{G} 1 \mathrm{P}$ and $20 \mathrm{mM} \mathrm{AcP}$ in $200 \mathrm{mM} \mathrm{K}^{+}$
HEPES buffer ( $\mathrm{pH} 7.2), 10 \%{ }^{2} \mathrm{H}_{2} \mathrm{O}(\mathrm{v} / \mathrm{v})$ and $1 \mathrm{mM}$ TSP with increasing concentrations of $\mathrm{MgCl}_{2}(5,10,20,30,50,100 \mathrm{mM})$. ${ }^{19} \mathrm{~F}$ experiments were recorded at $278 \mathrm{~K}$ using a Bruker $500 \mathrm{MHz}$ Avance III spectrometer (operating at $470.59 \mathrm{MHz}$ for ${ }^{19} \mathrm{~F}$ ) equipped with a $5 \mathrm{~mm}$ QCI-F cryoprobe and $z$-axis gradients running TopSpin version 3.5. One-dimensional experiments consisting of 16384 transients were recorded with a recycle delay of $1 \mathrm{~s}$ and took $352 \mathrm{~min}$ to acquire. Samples of $0.5 \mathrm{mM} \beta \mathrm{PGM}_{\mathrm{D} 170 \mathrm{~N}}$ were prepared in $200 \mathrm{mM} \mathrm{K} \mathrm{K}^{+}$HEPES buffer ( $\mathrm{pH}$ 7.2) containing $5 \mathrm{mM}$ or $100 \mathrm{mM} \mathrm{MgCl}_{2}, 10 \mathrm{mM} \mathrm{NaF}$, $0.2 \mathrm{mM}$ deferoxamine, $10 \%{ }^{2} \mathrm{H}_{2} \mathrm{O}(\mathrm{v} / \mathrm{v})$ and $1 \mathrm{mM}$ TSP. ${ }^{1} \mathrm{H}^{15} \mathrm{~N}$-TROSY NMR spectra were recorded for $\beta \mathrm{PGM}_{\mathrm{WT}}$ using a Bruker $500 \mathrm{MHz}$ Avance III spectrometer equipped with a $5 \mathrm{~mm}$ QCI-F cryoprobe and $z$-axis gradients running TopSpin version 3.5. The sample contained $1 \mathrm{mM}{ }^{15} \mathrm{~N}-\beta \mathrm{PGM}_{\mathrm{WT}}$ in $50 \mathrm{mM} \mathrm{K}{ }^{+}$HEPES buffer ( $\mathrm{pH} 7.2$ ) with $5 \mathrm{mM} \mathrm{MgCl}_{2}, 2 \mathrm{mM}$ $\mathrm{NaN}_{3}, 10 \%$ (v/v) ${ }^{2} \mathrm{H}_{2} \mathrm{O}$ and $1 \mathrm{mM}$ TSP. ${ }^{1} \mathrm{H}^{15} \mathrm{~N}-\mathrm{TROSY}$ NMR spectra were recorded for $\beta \mathrm{PGM}_{\mathrm{D} 170 \mathrm{~N}}$ using a Bruker $800 \mathrm{MHz}$ Neo spectrometer equipped with a $5 \mathrm{~mm}$ TCI cryoprobe and $z$-axis gradients running TopSpin version 4.0. The sample contained $0.5 \mathrm{mM}{ }^{15} \mathrm{~N}-\beta \mathrm{PGM}_{\mathrm{D} 170 \mathrm{~N}}$ (preincubated at $25{ }^{\circ} \mathrm{C}$ either for $0 \mathrm{~h}, 24 \mathrm{~h}$ or $48 \mathrm{~h}$ ) in $50 \mathrm{mM} \mathrm{K}{ }^{+}$HEPES buffer ( $\mathrm{pH}$ 7.2) with $5 \mathrm{mM} \mathrm{MgCl}_{2}, 2 \mathrm{mM} \mathrm{NaN}_{3}, 10 \%$ (v/v) ${ }^{2} \mathrm{H}_{2} \mathrm{O}$ and $1 \mathrm{mM}$ TSP. ${ }^{1} \mathrm{H}^{15} \mathrm{~N}$-TROSY experiments were acquired with 16 transients with 256 increments and spectral widths of 32 or $36 \mathrm{ppm}$ centred at $120 \mathrm{ppm}$ or $118 \mathrm{ppm}$ in the indirect ${ }^{15} \mathrm{~N}$ dimension. For the final $\beta$ G16BP product prepared in $100 \%{ }^{2} \mathrm{H}_{2} \mathrm{O}$ containing $1 \mathrm{mM}$ TSP, ${ }^{1} \mathrm{H}$ and natural abundance ${ }^{1} \mathrm{H}^{13} \mathrm{C}-\mathrm{HSQC}$ experiments were recorded using standard Bruker pulse sequences on an $800 \mathrm{MHz}$ Bruker Neo spectrometer with a $5 \mathrm{~mm}$ TCI cryoprobe equipped with $z$-axis gradients and running TopSpin version 4.0. ${ }^{31} \mathrm{P}$ experiments were also recorded for this sample, as described above. ${ }^{1} \mathrm{H}$ and ${ }^{13} \mathrm{C}$ chemical shifts were referenced to TSP resonating at $0.0 \mathrm{ppm} .{ }^{31} \mathrm{P}$ experiments were either referenced to $1 \mathrm{M} \mathrm{H}_{3} \mathrm{PO}_{4}$ resonating at $0.0 \mathrm{ppm}$, sealed inside a glass capillary and inserted into the sample NMR tube or were referenced indirectly to TSP using the gyromagnetic ratios of the ${ }^{1} \mathrm{H}$ and ${ }^{31} \mathrm{P}$ nuclei. ${ }^{19} \mathrm{~F}$ experiments were referenced indirectly to TSP using the gyromagnetic ratios of the ${ }^{1} \mathrm{H}$ and ${ }^{19} \mathrm{~F}$ nuclei. NMR data were processed with baseline correction and Lorentzian apodisation using either FELIX (Felix NMR, Inc.) or TopSpin version 4.0 (Bruker). Quantitative NMR experiments were performed using a recycle delay of 60 s. To measure apparent $K_{\mathrm{m}}\left(\mathrm{Mg}^{2+}\right)$ values from ${ }^{31} \mathrm{P}$ NMR timecourse experiments, the initial rate for the Step 1 production of $\beta$ G16BP and the Step 2 production of G6P was obtained using an in-house Python linear least-squares fitting program. The initial rates were subsequently fitted to eqn (1) using an in-house Python non-linear least-squares fitting program, which uses bootstrap error estimation.

$$
v_{0}=\frac{V_{\max }[\mathrm{A}]}{K_{\mathrm{m}(\mathrm{app})}+[\mathrm{A}]}
$$

where $v_{0}$ represents the initial rate of reaction, $A$ represents the activator being tested, $V_{\max }$ represents the apparent maximal 
rate, $K_{\mathrm{m}(\mathrm{app})}$ represents the apparent Michaelis constant for activation of the enzyme by $A$.

\section{Kinetic assays}

Kinetic assays for $\beta \mathrm{PGM}_{\mathrm{WT}}$ and $\beta \mathrm{PGM}_{\mathrm{D} 170 \mathrm{~N}}$ were conducted using a G6PDH coupled assay. Here, the G6P product of $\beta \mathrm{PGM}$ activity is oxidised to 6-phosphogluconolactone by G6PDH, while the concomitant reduction of $\mathrm{NAD}^{+}$to $\mathrm{NADH}$ is monitored by measuring changes in absorbance at $340 \mathrm{~nm}\left(\varepsilon_{340}=\right.$ $6220 \mathrm{M}^{-1} \mathrm{~cm}^{-1}$ ). Reactions were run at $25^{\circ} \mathrm{C}$ using a FLUOstar OMEGA microplate reader (BMG Labtech). To measure the $\mathrm{MgCl}_{2}$ dependence of the $\beta \mathrm{PGM}_{\mathrm{WT}} \mathrm{T}^{-}$and $\beta \mathrm{PGM}_{\mathrm{D} 170 \mathrm{~N}^{-}}$-catalysed conversion of $\beta$ G1P to G6P, reactions $(160 \mu \mathrm{L})$ were conducted in $200 \mathrm{mM} \mathrm{K}^{+}$HEPES buffer ( $\mathrm{pH}$ 7.2) containing different concentrations of $\mathrm{MgCl}_{2}(0,0.1,0.3,0.6,1.0,1.5,2.5,5,10,20,50$ and $100 \mathrm{mM}), 1 \mathrm{mM} \mathrm{NAD}^{+}, 5 \mathrm{U} \mathrm{mL}^{-1} \mathrm{G} 6 \mathrm{PDH}, 1 \mathrm{mM} \beta \mathrm{G} 1 \mathrm{P}$ and either $1 \mathrm{nM} \quad \beta \mathrm{PGM}_{\mathrm{WT}}$ with $100 \mu \mathrm{M} \quad \beta \mathrm{G} 16 \mathrm{BP}$, or $10 \mu \mathrm{M}$ $\beta \mathrm{PGM}_{\mathrm{D} 170 \mathrm{~N}}$ with $1250 \mu \mathrm{M} \beta \mathrm{G} 16 \mathrm{BP}$. Initial rates of the reactions were obtained using an in-house Python linear least-squares fitting program. Initial rates were subsequently fitted to eqn (2) using an in-house Python non-linear least-squares fitting program, which uses bootstrap error estimation.

$$
v_{0}=\frac{V_{\max }[\mathrm{A}]}{K_{\mathrm{m}(\mathrm{app})}+[\mathrm{A}]\left(\frac{1+[\mathrm{A}]}{K_{\mathrm{i}}}\right)}
$$

where $v_{0}$ represents the initial rate of reaction, $A$ represents the activator being tested, $V_{\max }$ represents the apparent maximal rate, $K_{\mathrm{m}(\mathrm{app})}$ represents the apparent Michaelis constant for activation of the enzyme by $A$ and $K_{\mathrm{i}}$ represents the apparent inhibition constant of the enzyme for $A$. To measure the apparent $K_{\mathrm{m}}(\beta \mathrm{G} 16 \mathrm{BP})$ of $\beta \mathrm{PGM}_{\mathrm{D} 170 \mathrm{~N}}$, reactions $(160 \mu \mathrm{L})$ were conducted in $200 \mathrm{mM} \mathrm{K}^{+}$HEPES buffer ( $\left.\mathrm{pH} 7.2\right)$ with $5 \mathrm{mM}$ $\mathrm{MgCl}_{2}, 1 \mathrm{mM} \mathrm{NAD}{ }^{+}, 5 \mathrm{U} \mathrm{mL}^{-1} \mathrm{G} 6 \mathrm{PDH}, 10 \mu \mathrm{M} \beta \mathrm{PGM}_{\mathrm{D} 170 \mathrm{~N}}$ and $1 \mathrm{mM} \beta \mathrm{G} 1 \mathrm{P}$, and were initiated using increasing concentrations of $\beta \mathrm{G} 16 \mathrm{BP}(10,25,50,100,150,250,350,750,1000$, $1500,2500 \mu \mathrm{M})$. Initial rates of G6P production were obtained using a linear least-squares fitting routine and these rates were subsequently fitted to eqn (1) using an in-house Python nonlinear least squares fitting program. To measure the dependence of initial reaction velocity for $\beta \mathrm{PGM}_{\mathrm{D} 170 \mathrm{~N}}$ on $\beta \mathrm{G} 1 \mathrm{P}$ concentration, reactions $(160 \mu \mathrm{L})$ were conducted in $200 \mathrm{mM} \mathrm{K}^{+}$ HEPES buffer $(\mathrm{pH} 7.2)$ with $5 \mathrm{mM} \mathrm{MgCl}_{2}, 1 \mathrm{mM} \mathrm{NAD}^{+}$, $5 \mathrm{U} \mathrm{mL}^{-1} \mathrm{G} 6 \mathrm{PDH}, 10 \mu \mathrm{M} \beta \mathrm{PGM}_{\mathrm{D} 170 \mathrm{~N}}$ and increasing concentrations of $\beta \mathrm{G} 1 \mathrm{P}(50,100,200,300,500,700,1000,1500,2000$, $3000,5000 \mu \mathrm{M}$ ) and were initiated using $250 \mu \mathrm{M} \beta \mathrm{G} 16 \mathrm{BP}$. Initial rates of G6P production were obtained using a linear least-squares fitting routine and these rates were subsequently fitted to eqn (2) to derive values for apparent $K_{\mathrm{m}}(\beta \mathrm{G} 1 \mathrm{P})$ and apparent $K_{\mathrm{i}}(\beta \mathrm{G} 1 \mathrm{P})$. To measure the effect of different phosphorylating agents on the $\beta \mathrm{PGM}_{\mathrm{WT}}$-catalysed conversion of $\beta$ G1P to G6P, reactions $(160 \mu \mathrm{L})$ were conducted in $200 \mathrm{mM} \mathrm{K}^{+}$ HEPES buffer ( $\mathrm{pH}$ 7.2) with $5 \mathrm{mM} \mathrm{MgCl}_{2}, 1 \mathrm{mM} \mathrm{NAD}^{+}$, $5 \mathrm{U} \mathrm{mL}^{-1} \mathrm{G} 6 \mathrm{PDH}, 5 \mathrm{nM} \beta_{\mathrm{PGM}} \mathrm{WT}, 50 \mu \mathrm{M} \beta \mathrm{G} 1 \mathrm{P}$ with either $1 \mu \mathrm{M}$ of the final $\beta \mathrm{G} 16 \mathrm{BP}$ product or $8 \mathrm{mM} \mathrm{AcP}$ as the phosphorylating agent. Blank absorbance measurements were obtained using solutions identical to the reaction mixtures, but without the addition of $\beta$ PGM.

\section{BG1P preparation}

$\beta$ G1P was prepared enzymatically from maltose using maltose phosphorylase (EC 2.4.1.8). A solution of $611 \mathrm{mM}$ maltose was incubated overnight with $1.2 \mathrm{U} \mathrm{mL}^{-1}$ maltose phosphorylase in $0.5 \mathrm{M}$ sodium phosphate buffer $(\mathrm{pH} 7.0)$ at $30{ }^{\circ} \mathrm{C}$. The production of $\beta \mathrm{G} 1 \mathrm{P}$ was confirmed using ${ }^{31} \mathrm{P}$ NMR spectroscopy. Maltose phosphorylase (molecular weight $=90 \mathrm{kDa}$ ) was removed from the solution by centrifugation using a Vivaspin (5 kDa molecular weight cut off; Sartorius). The concentration of $\beta \mathrm{G} 1 \mathrm{P}$ in the flow-through was measured to be $149 \mathrm{mM}$ using quantitative ${ }^{31} \mathrm{P}$ NMR experiments in which a known amount of G6P had been added to a sample of the $\beta$ G1P product, along with $10 \%$ ${ }^{2} \mathrm{H}_{2} \mathrm{O}(\mathrm{v} / \mathrm{v})$ and $1 \mathrm{mM}$ TSP. This concentration represents a yield of $24 \%$. The $\beta \mathrm{G} 1 \mathrm{P}$ product was contaminated with glucose, maltose and $\mathrm{P}_{\mathrm{i}}$ (estimated concentrations were $150 \mathrm{mM}, 850 \mathrm{mM}$ and $350 \mathrm{mM}$, respectively), and was not purified further since these compounds are bystanders in the reaction catalysed by $\beta$ PGM.

\section{$\beta$ G16BP production and purification}

A $15 \mathrm{~mL}$ reaction was prepared containing $20 \mu \mathrm{M} \beta \mathrm{PGM}_{\mathrm{D} 170 \mathrm{~N}}$ in $200 \mathrm{mM} \mathrm{K}^{+}$HEPES buffer together with $100 \mathrm{mM} \mathrm{MgCl}_{2}$, $2 \mathrm{mM} \mathrm{NaN}_{3}, 20 \mathrm{mM} \beta \mathrm{G} 1 \mathrm{P}$ and was initiated with $40 \mathrm{mM} \mathrm{AcP}$. The concentration of $\beta$ G16BP reached a maximum after $265 \mathrm{~min}$, whereupon the reaction was quenched by heat-denaturation of $\beta \mathrm{PGM}_{\mathrm{D} 170 \mathrm{~N}}$ at $90{ }^{\circ} \mathrm{C}$ for $10 \mathrm{~min}$. Precipitated enzyme was pelleted using centrifugation (Sigma Model 3-15) and the $\beta$ G16BP-rich supernatant was collected and filtered with a Vivaspin (5 kDa molecular weight cut off; Sartorius) using a benchtop centrifuge (Thermo Scientific Heraeus Labofuge $400 \mathrm{R}$ ). The resulting enzyme-free solution was passed through a $20 \times 10 \mathrm{~mm}$ column packed with $\mathrm{IR} 120\left(\mathrm{H}^{+}\right)$ ion-exchange resin, which had been washed with $15 \mathrm{~mL}$ of milliQ water. This step acidified the solution, which was then neutralised using $0.2 \mathrm{M}$ barium hydroxide solution, resulting in significant precipitation. The solution was kept on ice during neutralisation to increase the solubility of the monophosphorylated glucosaccharide barium salts. ${ }^{31}$ Fractions obtained along the course of the barium salt formation were analysed using ${ }^{31} \mathrm{P}$ NMR experiments, which indicated that the $\beta$ G16BP barium salt was contained mainly in the precipitate, and that the $\beta$ G1P and G6P barium salts remained in solution. The precipitate was pelleted using centrifugation at $4{ }^{\circ} \mathrm{C}$ (4500 rpm, Thermo Scientific Heraeus Labofuge $400 \mathrm{R}$ ) and the supernatant was discarded. To convert the $\beta \mathrm{G} 16 \mathrm{BP}$ barium salt to the more soluble sodium salt the pellet was resolubilised in a large volume $(\sim 1 \mathrm{~L})$ of cold milliQ water and passed through a $20 \times 10 \mathrm{~mm}$ column packed with IR120 $\left(\mathrm{Na}^{+}\right)$ion-exchange resin. The flow-through was then frozen at $-80{ }^{\circ} \mathrm{C}$ and lyophilised to leave a fine powder as the final $\beta \mathrm{G} 16 \mathrm{BP}$ product. 


\section{Conflicts of interest}

There are no conflicts to declare.

\section{Acknowledgements}

We would like to thank Prof. Nicholas Williams for useful insight into $\beta \mathrm{G} 16 \mathrm{BP}$ purification. This research was supported by the Biotechnology and Biological Sciences Research Council (BBSRC; H. P. W. - Grant Number X/009906-20-26, N. J. B. Grant Number BB/M021637/1 and BB/S007965/1, C. R. T. Grant Number BB/P007066/1) and Consejo Nacional de Ciencia y Tecnologia, Mexico (CONACYT; F. A. C. N. - Grant Number 472448).

\section{References}

1 P.-S. Huang, S. E. Boyken and D. Baker, The coming of age of de novo protein design, Nature, 2016, 357, 320-327.

2 K. Chen and F. H. Arnold, Engineering new catalytic activities in enzymes, Nat. Catal., 2020, 3, 203-213.

3 D. N. Bolon and S. L. Mayo, Enzyme-like proteins by computational design, Proc. Natl. Acad. Sci. U. S. A., 2001, 98, 14274-14279.

4 F. Wen, N. U. Nair and H. Zhao, Protein engineering in designing tailored enzymes and microorganisms for biofuels production, Curr. Opin. Biotechnol., 2009, 20, 412-419.

5 A. Zanghellini, De novo computational enzyme design, Curr. Opin. Biotechnol., 2014, 29, 132-138.

6 S. Yoshida, K. Hiraga, T. Takehana, I. Taniguchi, H. Yamaji, Y. Maeda, K. Toyohara, K. Miyamoto, Y. Kimura and K. Oda, A bacterium that degrades and assimilates poly(ethylene terephthalate), Science, 2016, 351, 1196-1199.

7 R. Wolfenden and M. J. Snider, The depth of chemical time and the power of enzymes as catalysts, Acc. Chem. Res., 2001, 34, 938-945.

8 C. Lad, N. H. Williams and R. Wolfenden, The rate of hydrolysis of phosphomonoester dianions and the exceptional catalytic proficiencies of protein and inositol phosphatases, Proc. Natl. Acad. Sci. U. S. A., 2003, 100, 5607-5610.

9 S. Jones and D. Selitsianos, A simple and effective method for phosphoryl transfer using $\mathrm{TiCl}_{4}$ catalysis, Org. Lett., 2002, 4, 3671-3673.

10 S. Jones, D. Selitsianos, K. J. Thompson and S. M. Toms, An improved method for Lewis acid catalyzed phosphoryl transfer with $\mathrm{Ti}(t-\mathrm{BuO})_{4}$, J. Org. Chem., 2003, 68, 52115216.

11 J. Dai, L. Finci, C. Zhang, S. Lahiri, G. Zhang, E. Peisach, K. N. Allen and D. Dunaway-Mariano, Analysis of the structural determinants underlying discrimination between substrate and solvent in $\beta$-phosphoglucomutase catalysis, Biochemistry, 2009, 48, 1984-1995.

12 M. Goličnik, L. F. Olguin, G. Feng, N. J. Baxter, J. P. Waltho, N. H. Williams and F. Hollfelder, Kinetic analysis of $\beta$-phosphoglucomutase and its inhibition by magnesium fluoride, J. Am. Chem. Soc., 2009, 131, 1575-1588.

13 N. J. Baxter, M. W. Bowler, T. Alizadeh, M. J. Cliff, A. M. Hounslow, B. Wu, D. B. Berkowitz, N. H. Williams, G. M. Blackburn and J. P. Waltho, Atomic details of neartransition state conformers for enzyme phosphoryl transfer revealed by $\mathrm{MgF}_{3}{ }^{-}$rather than by phosphoranes, Proc. Natl. Acad. Sci. U. S. A., 2010, 107, 4555-4560.

14 B. Elsässer, S. Dohmeier-Fischer and G. Fels, Theoretical investigation of the enzymatic phosphoryl transfer of $\beta$-phosphoglucomutase: Revisiting both steps of the catalytic cycle, J. Mol. Model., 2012, 18, 3169-3179.

15 J. L. Griffin, M. W. Bowler, N. J. Baxter, K. N. Leigh, H. R. W. Dannatt, A. M. Hounslow, G. M. Blackburn, C. E. Webster, M. J. Cliff and J. P. Waltho, Near attack conformers dominate $\beta$-phosphoglucomutase complexes where geometry and charge distribution reflect those of substrate, Proc. Natl. Acad. Sci. U. S. A., 2012, 109, 69106915.

16 Y. Jin, D. Bhattasali, E. Pellegrini, S. M. Forget, N. J. Baxter, M. J. Cliff, M. W. Bowler, D. L. Jakeman, G. M. Blackburn and J. P. Waltho, $\alpha$-Fluorophosphonates reveal how a phosphomutase conserves transition state conformation over hexose recognition in its two-step reaction, Proc. Natl. Acad. Sci. U. S. A., 2014, 111, 12384-12389.

17 J. Dai, L. Wang, K. N. Allen, P. Rådström and D. DunawayMariano, Conformational cycling in $\beta$-phosphoglucomutase catalysis: Reorientation of the $\beta$-D-Glucose 1,6-(bis)phosphate intermediate, Biochemistry, 2006, 45, 7818-7824.

18 L. Johnson, A. J. Robertson, N. J. Baxter, C. R. Trevitt, C. Bisson, Y. Jin, H. P. Wood, A. M. Hounslow, M. J. Cliff, G. M. Blackburn, M. W. Bowler and J. P. Waltho, van der Waals contact between nucleophile and transferring phosphorous is insufficient to achieve enzyme transition-state architecture, ACS Catal., 2018, 8, 8140-8153.

19 G. Zhang, J. Dai, L. Wang, D. Dunaway-Mariano, L. W. Tremblay and K. N. Allen, Catalytic cycling in $\beta$-phosphoglucomutase: A kinetic and structural analysis, Biochemistry, 2005, 44, 9404-9416.

20 M. Monticelli, L. Liguori, M. Allocca, G. Andreotti and M. V. Cubellis, $\beta$-Glucose-1,6-bisphosphate stabilizes pathological phophomannomutase 2 mutants in vitro and represents a lead compound to develop pharmacological chaperones for the most common disorder of glycosylation, PMM2-CDG, Int. J. Mol. Sci., 2019, 20, 4164.

21 P. S. Chan, C. T. Black and B. J. Williams, Separation of cyclic 3',5'-AMP from ATPADP, and 5'-AMP by precipitation with inorganic compounds, Anal. Biochem., 1973, 55, 1625.

22 M. Carlson, J. D. Carter and J. Rohloff, Improved preparation of $2 \mathrm{M}$ triethylammonium bicarbonate, Green Chem. Lett. Rev., 2015, 8, 37-39.

23 H. P. Wood, F. A. Cruz-Navarrete, N. J. Baxter, C. R. Trevitt, A. J. Robertson, S. R. Dix, A. M. Hounslow, M. J. Cliff and J. P. Waltho, Allomorphy as a mechanism of post-transla- 
tional control of enzyme activity, Nat. Commun., 2020, 11, $1-12$.

24 N. J. Baxter, L. F. Olguin, M. Goličnik, G. Feng, A. M. Hounslow, W. Bermel, G. M. Blackburn, F. Hollfelder, J. P. Waltho and N. H. Williams, A Trojan horse transition state analogue generated by $\mathrm{MgF}_{3}{ }^{-}$formation in an enzyme active site, Proc. Natl. Acad. Sci. U. S. A., 2006, 103, 14732-14737.

25 F. Paradisi, J. L. Dean, K. F. Geoghegan and P. C. Engel, Spontaneous chemical reversion of an active site mutation: Deamidation of an asparagine residue replacing the catalytic aspartic acid of glutamate dehydrogenase, Biochemistry, 2005, 44, 3636-3643.

26 L. E. Holt, J. A. Pierce and C. N. Kajdi, The solubility of the phosphates of strontium, barium, and magnesium and their relation to the problem of calcification, J. Colloid Sci., 1954, 9, 409-426.
27 J. E. Seegmiller and B. L. Horecker, The synthesis of glucose-6-phosphate and 6-phosphogluconate, J. Biol. Chem., 1951, 192, 175-180.

28 D. M. Brown and D. A. Usher, Hydrolysis of hydroxyalkyl phosphate esters: The epoxide route, J. Chem. Soc., 1965, 1965, 6547-6558.

29 D. M. Brown and D. A. Usher, Hydrolysis of hydroxyalkyl phosphate esters: Effect of changing ester group, J. Chem. Soc., 1965, 1965, 6558-6564.

30 M. A. C. Reed, A. M. Hounslow, K. H. Sze, I. G. Barsukov, L. L. P. Hosszu, A. R. Clarke, C. J. Craven and J. P. Waltho, Effects of domain dissection on the folding and stability of the $43 \mathrm{kDa}$ protein PGK probed by NMR, J. Mol. Biol., 2003, 330, 1189-1201.

31 T. Posternak, Synthesis of $\alpha$ - and $\beta$-glucose-1,6-diphosphate, J. Biol. Chem., 1949, 180, 1269-1278. 